Illinois State University

ISU ReD: Research and eData

Theses and Dissertations

$12-5-2016$

\title{
Evaluating lithology as an erosional control on a fluviokarst system in northeastern Kentucky
}

Andrew K. Francis

Illinois State University, francisak4@gmail.com

Follow this and additional works at: https://ir.library.illinoisstate.edu/etd

Part of the Geography Commons, Geology Commons, and the Geomorphology Commons

\section{Recommended Citation}

Francis, Andrew K., "Evaluating lithology as an erosional control on a fluviokarst system in northeastern Kentucky" (2016). Theses and Dissertations. 669.

https://ir.library.illinoisstate.edu/etd/669

This Thesis is brought to you for free and open access by ISU ReD: Research and eData. It has been accepted for inclusion in Theses and Dissertations by an authorized administrator of ISU ReD: Research and eData. For more information, please contact ISUReD@ilstu.edu. 


\title{
EVALUATING LITHOLOGY AS AN EROSIONAL CONTROL ON A FLUVIOKARST SYSTEM IN NORTHEASTERN KENTUCKY
}

\author{
Andrew K. Francis
}

\section{Pages}

Longitudinal stream profiles can be used to evaluate landscape evolution. Lithology as a control on a stream profile is especially of interests because fluviokarst systems are characterized by the contact of carbonate and non-carbonate rocks at the surface. Due to the difference in weathering processes between carbonates and non-carbonate rocks, it is likely that there is a difference in their rates of erosion. Cave Branch and its tributary Horn Hollow, are fluviokarst systems located in northeastern Kentucky. This area is primarily comprised of sandstone and limestone. The objectives of this study were to determine if variation in lithology was creating a state of disequilibrium in the Cave Branch and Horn Hollow watersheds, determine whether sandstone or limestone erode at a faster rate in this system, and to assess how erosional resistance is related to the overall development of the system. Stream profiles were compared by calculating stream power values using an integral approach in which chi plots were created. This method allows for the comparison of streams of different drainage areas because erosion is scaled with drainage area. It was determined that sandstone watersheds were generally in a greater degree of equilibrium than the limestone watersheds, but whether variation in lithology was creating a state of disequilibrium in the whole watersheds was inconclusive. Limestone 
streams were determined to have a greater steepness index, greater resistance, than sandstone streams. The greater degree of disequilibrium and observed greater resistance of the limestone is related to the soluble nature of limestone, and the glacial-fluvial development of this area.

KEYWORDS: Karst, Fluviokarst, Geomorphology, Stream Profiles, Erosional Resistance, Stream Power 
EVALUATING LITHOLOGY AS AN EROSIONAL CONTROL ON A FLUVIOKARST SYSTEM IN NORTHEASTERN KENTUCKY

ANDREW K. FRANCIS

A Thesis Submitted in Partial Fulfillment of the Requirements for the Degree of

MASTER OF SCIENCE

Department of Geography-Geology

ILLINOIS STATE UNIVERSITY 
(C) 2017 Andrew K. Francis 
EVALUATING LITHOLOGY AS AN EROSIONAL CONTROL ON A FLUVIOKARST SYSTEM IN NORTHEASTERN KENTUCKY

ANDREW K. FRANCIS

COMMITTEE MEMBERS:

Eric W. Peterson, Chair

Toby Dogwiler

Rex J. Rowley 


\section{ACKNOWLEDGMENTS}

There are several people I would like to thank. I would like to thank my advisor Eric Peterson for his help throughout my time at Illinois State. Your assistance on this project and has made it a very rewarding and invaluable experience. I would also like to thank Toby Dogwiler and R.J. Rowley for their help on this project. Also thanks to everyone who attended the research meetings and provided feedback on my presentations and thesis writing, and Sam Schoemann for our many discussions on stream profiles. Thanks to my professors from Wittenberg Dr. Ritter and Dr. Zaleha. Thank you both for sparking my interest in geology and encouraging me to continue on to grad school. Lastly, I would also like to thank my parents, Stephen and Laura, my sister Erin, and my fiancé Emily for their continued support throughout this process.

A. K. F. 


\section{CONTENTS}

$\begin{array}{lr} & \text { Page } \\ \text { ACKNOWLEDGMENTS } & \text { i } \\ \text { CONTENTS } & \text { ii } \\ \text { TABLES } & \text { iv } \\ \text { EQUATIONS } & \text { v } \\ \text { FIGURES } & \text { vi } \\ \text { CHAPTER } & \end{array}$

$\begin{array}{lll}\text { I. } & \text { INTRODUCTION AND BACKGROUND } & 1\end{array}$

Stream Profiles $\quad 1$

Integral Method 3

Karst $\quad 5$

$\begin{array}{lr}\text { Study Area } & 7\end{array}$

Previous Work in This Region 11

$\begin{array}{ll}\text { Objective } & 12\end{array}$

$\begin{array}{ll}\text { II. } & 13\end{array}$

Geographic Information System (GIS) 13

$\begin{array}{ll}\text { MATLAB } & 17\end{array}$

$\begin{array}{ll}\text { III. } & \text { RESULTS }\end{array}$

$\begin{array}{ll}\text { Equilibrium Analysis } & 24\end{array}$

$\begin{array}{ll}\text { Sensitivity Analysis } & 30\end{array}$

Steepness Index (SI) Analysis 31

$\begin{array}{ll}\text { IV. DISCUSSION } & 33\end{array}$

$\begin{array}{lll}\text { V. CONCLUSION } & 39\end{array}$ 
REFERENCES 


\section{TABLES}

Table

1. Results from Equilibrium Analysis

2. Sensitivity Analysis of m/n Ratio for the Cave Branch Basin
Page

25

31 


\section{EQUATIONS}

Equation $\quad$ Page

1. Stream Power Equation 2

2. Stream Power Equation Using the Integral Approach 4

3. Chi, Integral of Drainage Area 4 


\section{FIGURES}

Figure $\quad$ Page

1. Example Stream Profile in a State of Equilibrium 3

2. Example Longitudinal Stream Profile Showing Karst Features Formed by Subsurface Piracy

3. Cave Branch Basin, Including Its Tributary Horn Hollow 9

4. Stratigraphic Column of Northeastern Kentucky 10

5. Flow Chart for Creating Watersheds In GIS, Which Consists of Two Processes 14

6. Cave Branch and Horn Hollow Watershed 16

7. Sub-Watersheds for Cave Branch and Horn Hollow Above 274 MASL 17

8. $\quad$ Outline for Chi Plot Analysis In MATLAB 18

9. Individual Watersheds with Corresponding Lithology 21

10. Log-Log Drainage Area-Slope Plot Used to Determine the Flow Accumulation That Constituted a Stream in The Cave Branch Basin

11. Cave Branch Chi Plot, Including Sandstone and Limestone Segments 26

12. $\mathrm{CB}<274$, Cave Branch Streams Below 274 MASL, Limestone Streams 26

13. CB274North, Cave Branch Chi Plot Above 274 MASL, Sandstone Streams 27

14. CBMid274, Cave Branch Chi Plot Above 274 MASL, Sandstone Streams 27

15. CBSouth274, Cave Branch Chi Plot Above 274 MASL, Sandstone Streams 28

16. Horn Hollow Chi Plot Including Sandstone and Limestone Streams 28

17. $\mathrm{HH}<274$, Horn Hollow Chi Plot Below 274 MASL, Limestone Streams 29

18. HH274East, Horn Hollow Chi Plot Above 274 MASL, Sandstone Streams 29 
19. HH274West, Horn Hollow Chi Plot Above 274 MASL, Sandstone Streams

20. Box Plot of SI Values of Sandstone and Limestone Streams

21. Chi Plot of Horn Hollow 


\section{CHAPTER I}

\section{INTRODUCTION AND BACKGROUND}

\section{Stream Profiles}

Many factors play a role in the development of a landscape. Overtime, the weathering and erosion of landscape will leave a record of environmental condition. One way to interpret past environmental conditions and to understand landscape evolution is to examine longitudinal stream profiles. A longitudinal stream profile plots the bed elevation against the length of the stream. The reason stream profiles are useful in the evaluation of a landscape is because they set the boundary for hillslope processes, which is responsible for the denudation of a landscape (Whipple and Tucker, 1999). As landscape denudation occurs, streams work to reach equilibrium conditions, where there is an equal amount of erosion and deposition. Equilibrium conditions result in a smooth concave-up profile (Mackin, 1948, Hack 1957, Goldrick and Bishop, 2007, Phillips and Lutz, 2008) (Figure 1). Additional factors can alter the rates of erosion and deposition causing a stream to deviate from equilibrium and lose its equilibrium profile. These factors include tectonics, climate, change in base level, and variation in erodibility and lithology (Phillips and Lutz, 2008). In bedrock streams, dominate erosional forces are closely related to lithology and structure of the underlying bedrock (Miller 1991, Wohl 1998, Wohl and Ikeda 1998).

Stream power is a measure of the sediment-transport capacity for a stream as it is related to discharge and slope (Hack, 1973, Knighton, 1998, Anthony and Granger, 2007, Phillips and 
Lutz, 2008). A stream's sediment-transport capacity is directly related to the shear stress. As shear stress increases, more erosion occurs, which effects the shape of a streams profile. Stream profiles can thus be quantified with the stream power equations. Stream power laws can predict the amount of erosion occurring along a stream’s profile; any significant deviation from this prediction represents a state of disequilibrium (Phillips and Lutz, 2008). A common stream power equation used to evaluate a stream profile is expressed in terms of drainage area and slope. Drainage area serves as a proxy for discharge. A common approach to modeling the evolution of a stream profile is to assume topographic steady-state (Perron and Royden, 2013). A stream power equation assuming topographic steady-state takes the following form.

$$
\frac{d z}{d x}=\frac{U}{K}^{1 / n} \times A(x)^{m / n}
$$

Equation 1. Stream power equation.

Where $z$ is elevation, $x$ is horizontal distance, $U$ is uplift, $K$ is erodibility, $A$ is drainage area, and $m$ and $n$ are exponents related to hydrologic conditions. Exponent's $m$ and $n$ are a function of standard flow resistance and stream power relations (Sklar and Diertrich, 1998, Phillips and Lutz, 2008). The ratio of $m / n$ represents the concavity index of a stream profile (Whipple and Tucker, 1999, Phillip and Lutz, 2008). This stream power model assumes a power-law relationship between drainage area and slope. 


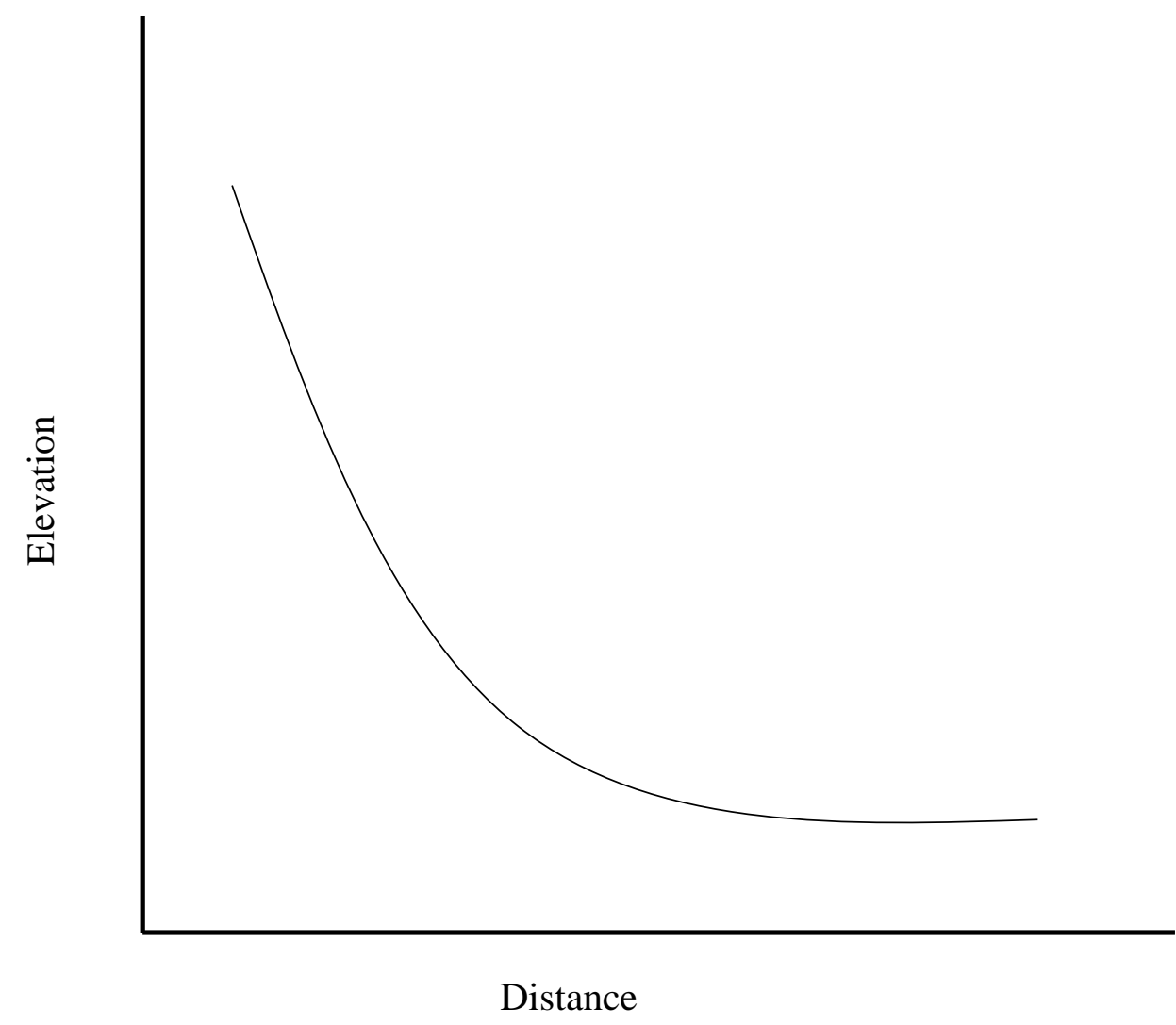

Figure 1. Example stream profile in a state of equilibrium.

\section{Integral Method}

Perron and Royden (2013) introduced a method of bedrock river profile analysis, derived from Equation (1), that calculates stream power by using elevation instead of slope as the dependent variable and the spatial integral of drainage area as the independent variable. The slope of the transformed profile, or chi plot, represents the steepness index (SI), which is equal to uplift over erodibility. The transformation of a stream profile is calculated from: 


$$
z(x)=z\left(x_{b}\right)+\left(\frac{U}{K A_{0}^{m}}\right)^{1 / n} X
$$

Equation 2. Stream power equation using the integral approach.

Where

$$
X=\int_{x_{b}}^{x}\left(\frac{A_{0}}{A(x)}\right)^{m / n} d x
$$

Equation 3. Chi, integral of drainage area.

The variables in Equations 2 and 3 have been defined in Equations (1), with the addition of $A_{0}$, which serves as a reference drainage area, and $X$ or chi, which is the integral of drainage area. A plot of elevation against $X$ is called a chi plot, and the slope of this plot represents the SI. The benefit to calculating stream power with this method is that erosion is scaled with drainage area, allowing for the comparison of main stems to tributaries. The integral method also removes noise that is a side effect of calculating slope from uncertain topographic data.

The integral method of stream power can indicate disequilibrium within a single stream or for an entire watershed. For a single stream, the chi plot should be linear, and any deviation from that suggests a state of disequilibrium. Because erosion is scaled with drainage area, the chi plot for an entire stream network should exhibit streams with similar slope, or SI. As previously discussed, disequilibrium in streams can be attributed to variations in erodibility. Understanding variations in erosion is especially of interest in a system that experiences different types of weathering. An example of this would be streams in a karst system. Karst, which is dominated by carbonate bedrock, is unique because it is subject to physical and chemical weathering. There 
has not been much work on karst systems from the perspective of stream profile analysis (White and White, 1983).

\section{Karst}

Karst describes a landscape that has distinct landforms and drainage that formed in rocks with greater than average solubility (Jennings, 1985). Karst forms in carbonate and evaporite rocks, but is most associated with limestone (Jakucs, 1977). Although an estimated $12.5 \%$ of Earth's surface is classified as karst, there is not a complete understanding how these systems evolve (Martin and White, 2008). The state of Kentucky is an example of an area that is predominantly underlain by karst limestone (Anthony and Granger, 2004). In a "traditional" karst system, limestone dissolution forms caves and conduits, creating a subsurface drainage system with a large variation of porosity and permeability. These variations and heterogeneity create a system that differs from a typical Darcian groundwater system (Ritter et al., 2011). An aspect of karst evolution is that much of the geomorphic alteration occurs underground and is not easily observed from the subsurface (Ritter et al., 2011).

Fluviokarst is a system with surface and subsurface drainage, consisting of fluvial and karst features. These systems typically occur at the contact of carbonate and non-carbonate rocks (Jakucs, 1977, Bocic, 2003). Lithology is a key component in the development of fluviokarst, and the difference in erosional resistance between lithologies will influence the landscape as a whole. Limestone is susceptible to both physical and chemical weathering. Dogwiler and Wicks (2004) found that physical weathering is more common in karst streams than had been previously reported. With respect to chemical weathering of limestone, streams in limestone bedrock can have unique features due to the flow being diverted into the subsurface and reemerging downstream due to dissolution. Anomalous bumps can develop in the profile of a 
limestone bedrock stream due to erosional process continuing downstream where water reemerges to the surface after being pirated upstream. Woodside et al. (2015) identified these anomalous features in a limestone bedrock stream as being a function of karst processes in a fluviokarst system in northeastern Kentucky. At the same time, Schroeder (2014) found that these anomalous features were not present in a fluviokarst system located in southeastern Minnesota. As previously mentioned, fluviokarst forms at the contact of carbonate and noncarbonate rocks. Non-carbonate rocks, specifically siliciclastic rocks, weather primarily by physical processes due to their low solubility. The solubility of quartz and other silicate minerals are relatively insoluble when compared to limestone (Nesbitt et al. 1997). Physical and chemical weathering of limestones as opposed to just physical weathering of siliciclastic rocks result in a result in erosional resistance.

One way to evaluate the potential difference in erosional resistance, is to analyze longitudinal stream profiles. Typically, karst systems are subterranean limiting the application of longitudinal stream profile analysis in karst settings. However, fluviokarst systems consist of at least some surface streams allowing for analysis of stream profiles. White and White (1983) conducted a study on stream profiles in a karst system and found that streams in the subsurface maintain a profile similar to that of a surface stream. They describe fluviokarst as streams that sink at the contact of limestone, and re-emerge from springs at base level, or at the contact of non-carbonate rocks, while maintaining an equilibrium profile. Similarly, Woodside et al. (2015) found streams diverted to the subsurface maintain an equilibrium profile. Subsurface streams can be exposed in karst windows, openings between caves that form due to collapse and expose what was once a subterranean river (Ritter et al. 2011). The anomalous bumps in limestone bedrock 
longitudinal stream profiles discussed by Woodside et al. (2015) are representative of caves, and the openings between the caves are thought to be the result of cave collapse (Figure 2).

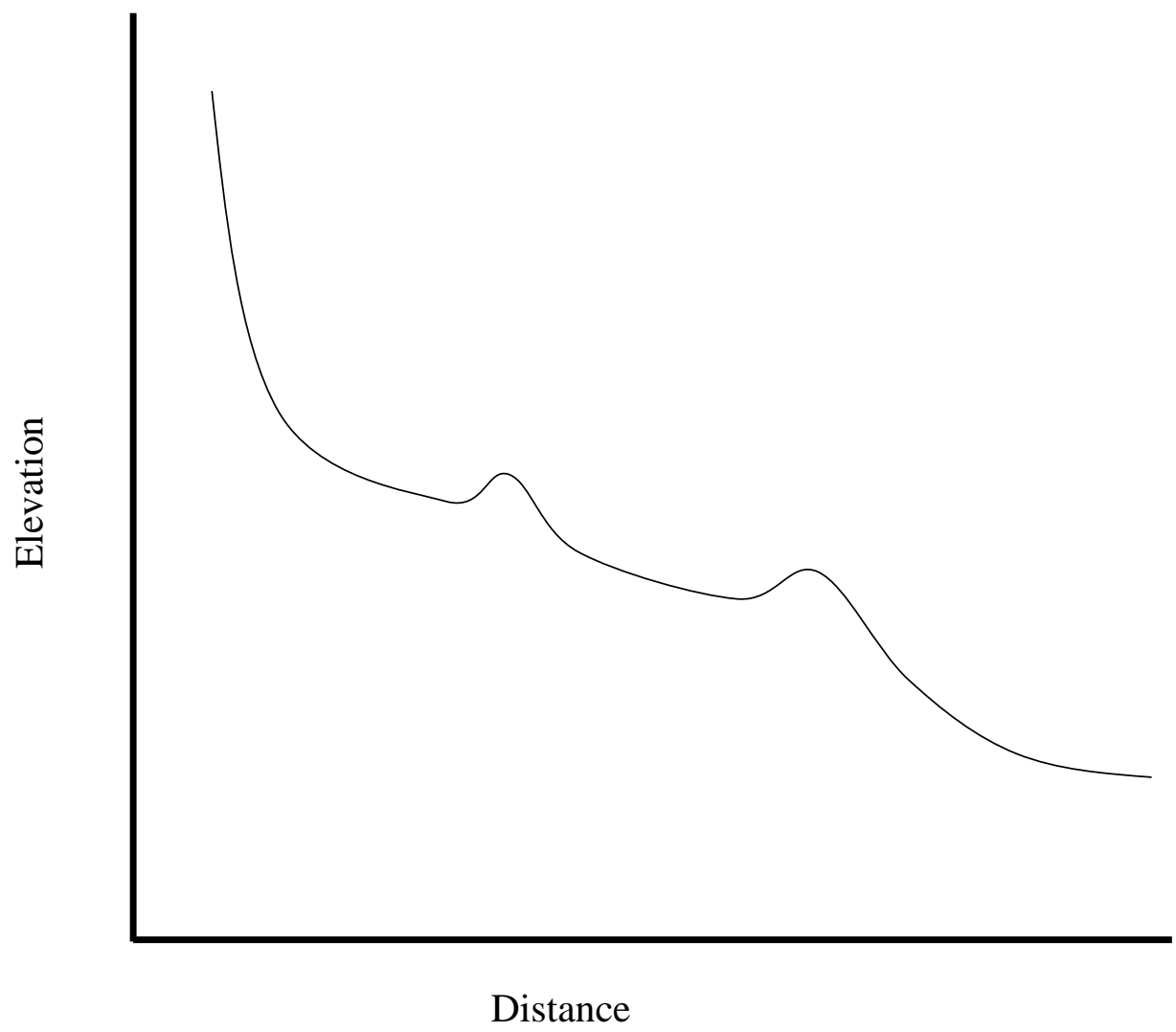

Figure 2. Example longitudinal stream profile showing karst features formed by subsurface piracy.

\section{Study Area}

Carter Caves State Resort Park (CCSRP), is located in northeastern Kentucky and has been extensively studied for its development as a fluviokarst system (Dogwiler and Wicks, 2004, Engel and Engel, 2009, Peterson et al., 2011, Jacoby et al., 2013, and Woodside et al., 2015). This study will focus on the Cave Branch and Horn Hollow Basins, each with sections inside and beyond the boundaries of CCSPR (Figure 3). Engel and Engel (2009) provide a detailed 
description of the regional stratigraphy and salient descriptions of bedrock within the integral units. CCSRP consists of Mississippian and Pennsylvanian age, with approximately 25 meters of carbonate bedrock bounded by siliciclastic units (Figure 4). The area is comprised of three formations: the Borden Formation, the Slade Formation, and the Paragon Formation. Borden Formation, the lower most Mississippian unit, consists of the Cowbell and Nada Members. The Cowbell Member is a 90-meter-thick sandstone with interbedded siltstones and shales. The Nada Member consists of interbedded shales. The Slade Formation, the next Mississippian, consists of the St. Louis, Ste. Genevieve, and upper-member Newman. The St. Louis Limestone is a veryfine to medium grain gray to yellow and tan limestone. The Ste. Genevieve Limestone is a white to light-gray limestone, formed in a shallow, subtidal environment. The Upper Newman consists of limestones, interbedded with red and gray chert silt and sand. The Paragon Formation, the upper unit, consists of the Carter Caves Sandstone, Lee, and Breathitt formations. The Carter Cave Sandstone is a fine to medium-grained, well-sorted quartz sandstone. Contact between the Carter Cave Sandstone and the underlying Newman Limestone occurs at 274 meters above sea level (MASL) (Jacoby et al., 2013). The Breathitt and Lee Formations consists of interbedded sandstones, siltstones, and coal beds. All formations have surface exposure; therefore, streams transition from clastic to carbonate to clastic moving towards the regional base level defined by Tygrat's Creek, which flows along the Borden formation and below all karst development. The area that will be evaluated in this study is within the Cave Branch and Horn Hollow Basin. The headwaters of the basins originate in the Carter Caves Sandstone. The units that underlie these watersheds are the Carter Cave Sandstone and the Upper Member Newman Limestone 


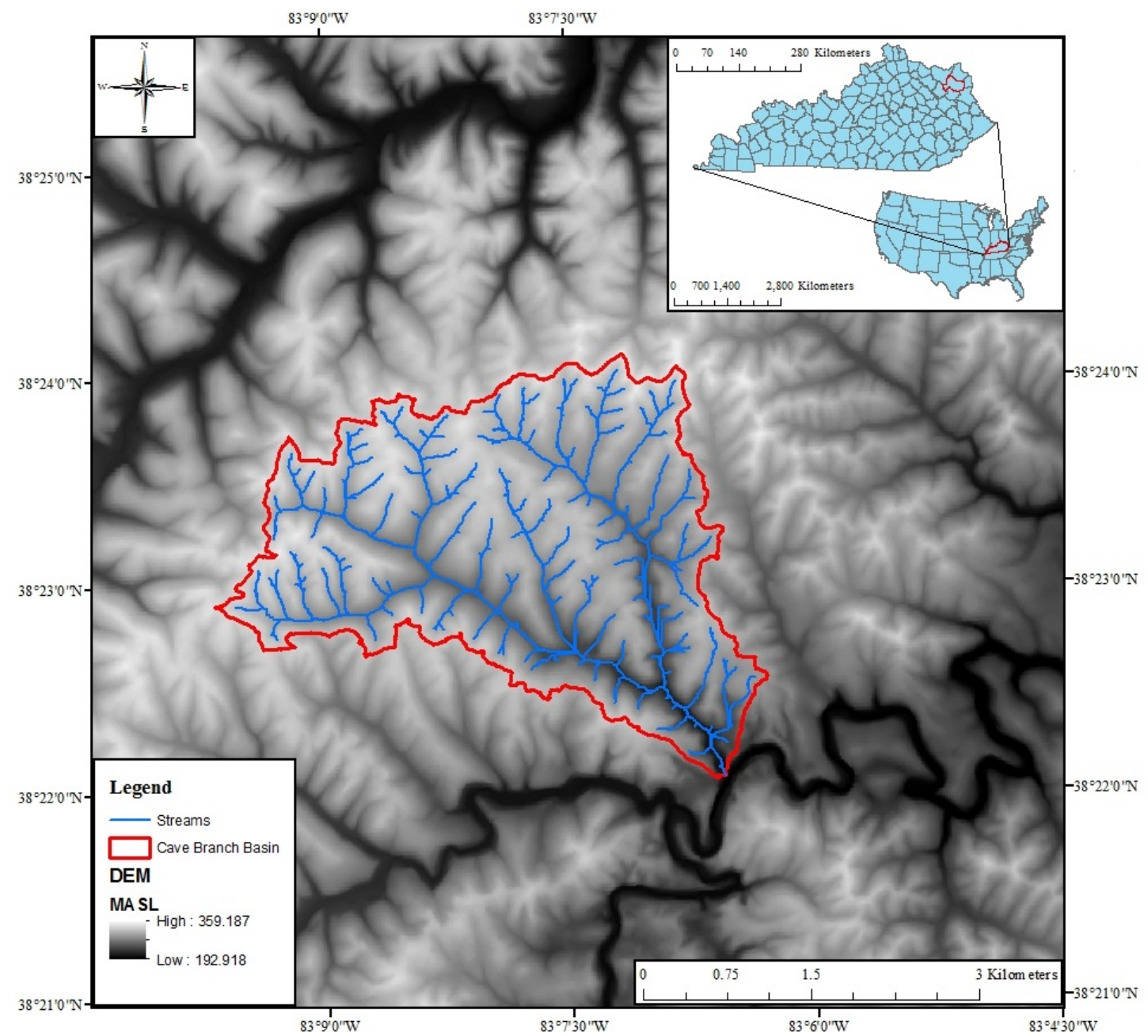

Figure 3. Cave Branch Basin, including its tributary Horn Hollow. Horn Hollow constitutes the northeastern part of the watershed. 


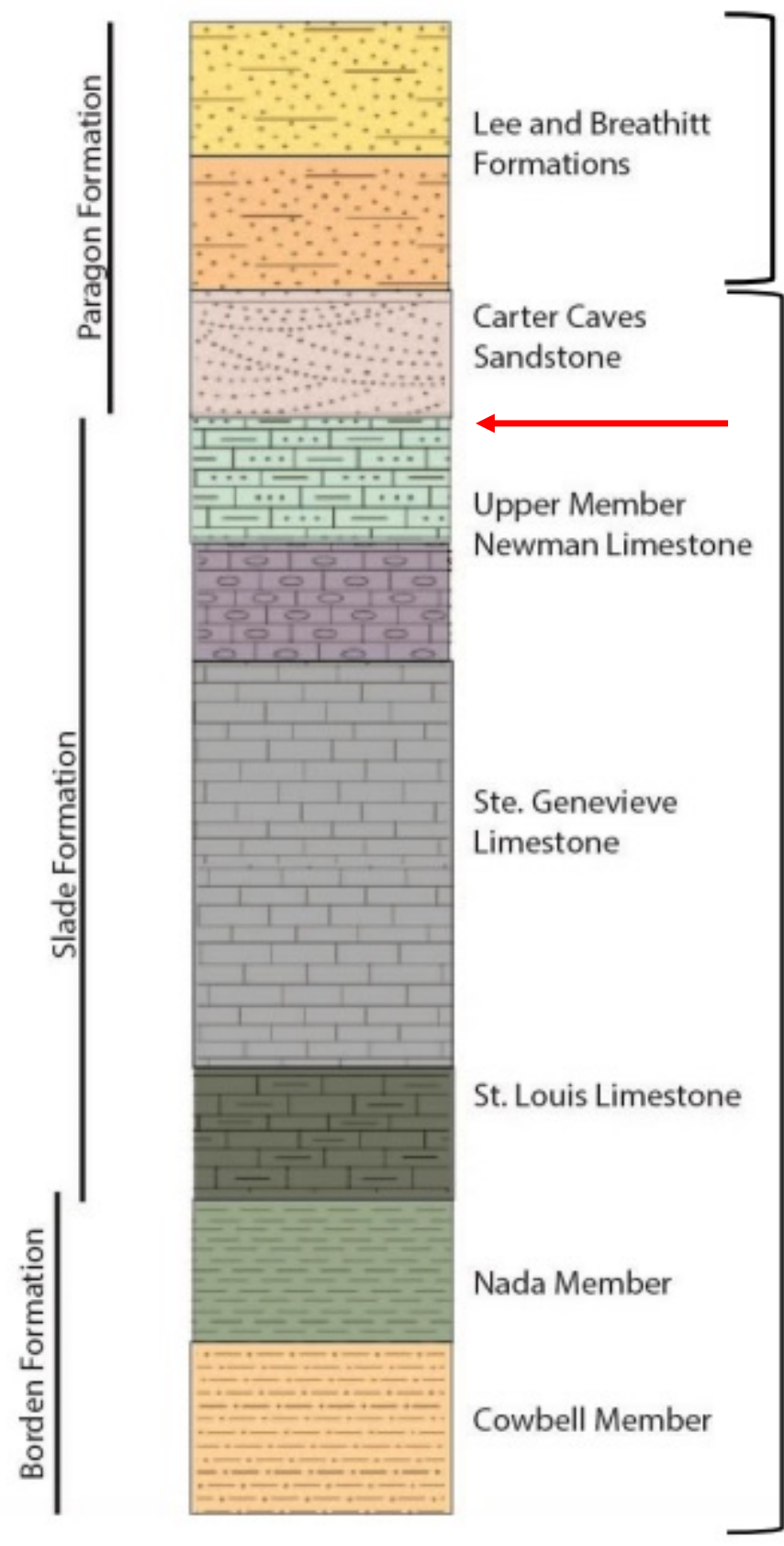

Pennsylvanian

Mississippian

Figure 4. Stratigraphic column of northeastern Kentucky. Red arrow represents 274 MASL. 


\section{Previous Work in This Region}

Woodside et al. (2015) looked at the presence of anomalous bumps in the profiles of, Horn Hollow Creek, a limestone bedrock stream in CCSRP. These bumps in the profile are associated with subsurface stream piracy, where the piracy results in a decrease in erosion at the surface downstream. Even with the presence of anomalies, and most of the water being diverted into the subsurface, the profile of the stream represents near equilibrium conditions. The study looked at whether sediment mobility could serve as a proxy for anomalous areas, and if crosssectional profiles could reveal areas of cave collapse and natural downcutting. They found that sediment distribution does not follow the progression of typical fining-out pattern which is directly related to the anomalous sections affecting the hydraulics of the stream. The crosssectional areas also were possible indicators of downcutting and cave collapse. Sections of the streams bounded near vertical walls likely formed due to cave collapse, and areas of stream with a v-shaped channel are likely a function of natural downcutting. The final conclusion of the study was that the longitudinal profile of the limestone stream is strongly influenced by karst processes.

Schroeder (2014) looked to identify the same anomalous features in separate fluviokarst system located in southeastern Minnesota. The area is a more mature fluviokarst system that had started to develop prior to the last glacial episode. No anomalous segments were observed in streams due to subsurface piracy. Any bumps observed in the profile of streams were due to pool-riffle sequences.

Peterson et al. (2011) determined there were four cave levels within the CCSRP with the use of a 30-meter DEM (digital elevation model). And, Jacoby et al. (2013) looked to more accurately measure the elevation of the cave levels with a 10-meter DEM. Multiple cave levels 
have developed due to changes in base level associated with glacio-eustatic processes, which led to the formation of the Ohio River and the abandonment of the Teays River Valley (Tierney, 1985). Being able to accurately determine the elevation of cave levels is useful for the interpretation of landscape history. These four distinct cave levels observed in this work were the result of static base levels, and show how the system responded to subsurface drainage helping to explain the development of what was observed in Woodside et al (2015). Jacoby et al. (2011) found that there was no correlation between areas of higher sensitivity to erosion and areas of higher cave density.

\section{Objective}

The presence of anomalous segments in fluviokarst streams were observed in northeastern Kentucky, but not in southeastern Minnesota. To further understand this dichotomy, evaluating difference in erodibility based on lithology would be useful. The purpose of this study is to determine if lithology is a controlling factor in the development of the fluviokarst system

located in CCSRP in northeastern Kentucky. The objectives of this study are to (1) determine if a state of disequilibrium exists because of a variation in lithology; (2) determine whether the limestone or sandstone is more resistant to erosion based on stream power; and (3) assess how erosional resistance is related to the overall development of the system. 


\section{CHAPTER II}

\section{METHODS}

To further understand the development of fluviokarst systems, streams were evaluated using a stream power model. The stream power model served to answer the three objectives in this study. The integral method introduced by Perron and Royden (2013) and presented above, was used to conduct the profile analyses. The benefit of this method is that it scales erosion with drainage area. This aspect of erosion being scaled with drainage area is crucial to this study because it allows to determine whether or not an entire watershed is in a state of equilibrium because of varying lithology. Tributaries and the main stem in a watershed should erode at relatively the same rate. We can also use this method to compare the upstream and downstream segments allowing a comparison of the erodibility of the Carter Cave Sandstone and the Upper Member Newman Limestone. Once we determine whether or not the watershed is in disequilibrium based on lithology and whether limestone or sandstone is eroding at a faster rate, the third objective of this work can be addressed which is to understand how variation in lithology may influences the overall development of a fluviokarst system.

\section{Geographic Information System (GIS)}

To that end, the first step was to create individual watersheds, which were generated in ArcGIS 10.3.1. 10-meter DEMs were downloaded from the USGS 3D Elevation Program. The Cave Branch watershed and sub-watersheds were delineated by placing a pour point on a DEM aided by the creation of a stream network. After the DEM of the CCSRP area was downloaded, 
the following process was taken to create a stream network that allowed for the creation of individual watersheds (Figure 5).

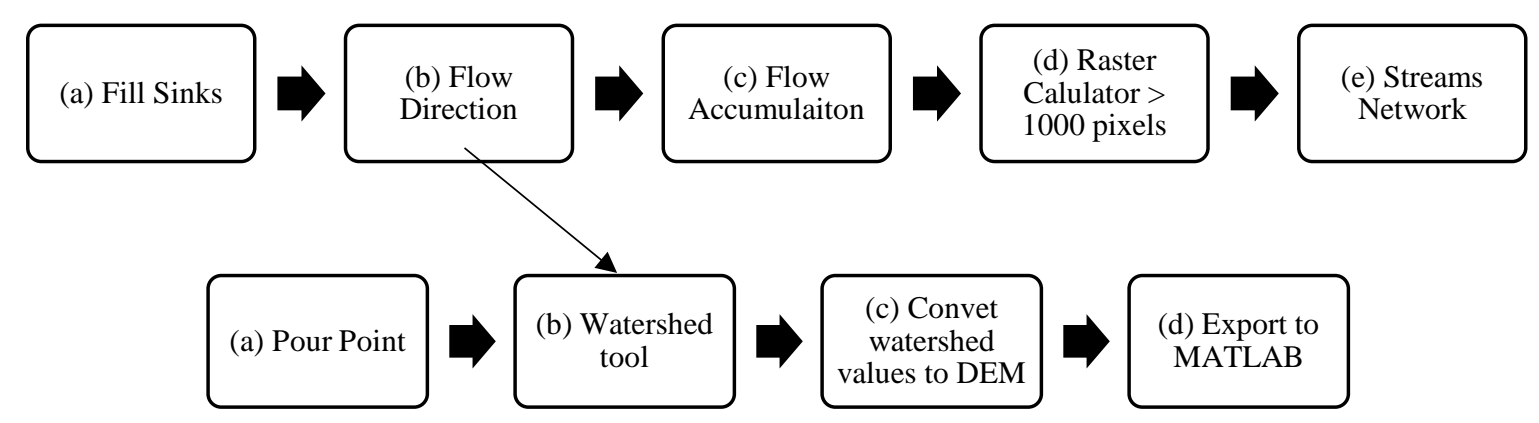

Figure 5. Flow chart for creating watersheds in GIS, which consists of two processes.

The first process consists of five steps. First, we filled sinks in the DEM, those areas that are irregularly low (or high) relative to neighboring pixels. Next, we use the filled DEM to identify the flow direction for each cell. Using a flow accumulation process then determines the total number of cells draining to each cell. Finally, we used Raster Calculator to select all cells where more than a 1000 cells are draining to it (e.g., the collection points for a significant amount of surface flow). A sequence of cells with a 1000 or more cells draining to it represents a stream. With a 10-meter DEM, 1000 cell drainage area represents 100,000 $\mathrm{m}^{2}$. Thus, the threshold of 1000 cells represent the transition from colluvial to fluvial, which occurs when the drainage area of a watershed ranges from $10^{5}$ to $10^{6} \mathrm{~m}^{2}$ (Whipple and Tucker, 1999).

The second process consists of four steps. First we identified a pour point that is used to create the individual watersheds. Pour points were placed at the confluence of Cave Branch and Horn Hollow, and five locations up stream at 274 MASL, the contact between the upstream 
sandstone and the downstream limestone. The stream network created in the first process was used to assistant in the placement of the pour points. Next, we computed the watershed boundaries, which involves computing all of the cells with directional flow (from the flow direction layer generated in the first process, the output from step b) leading to that pour point. Watersheds were created for both Cave Branch, upstream from the confluence with Horn Hollow, and Horn Hollow (Figure 6). Within the Cave Branch watershed, the use of a pour point at 274 MASL generates three upstream sub-watersheds, which are named CB274 north, mid, and south. Within the Horn Hollow watershed, two upstream sub-watersheds were created, HH274 west and east (Figure 7). The individual watersheds were then manipulated by converting the pixel values to 1 , then multiplied by the values of the DEM. Thus, creating a watershed that was “clipped” from the DEM. Last, the DEM watersheds were and exported to MATLAB to conduct stream power calculations. 


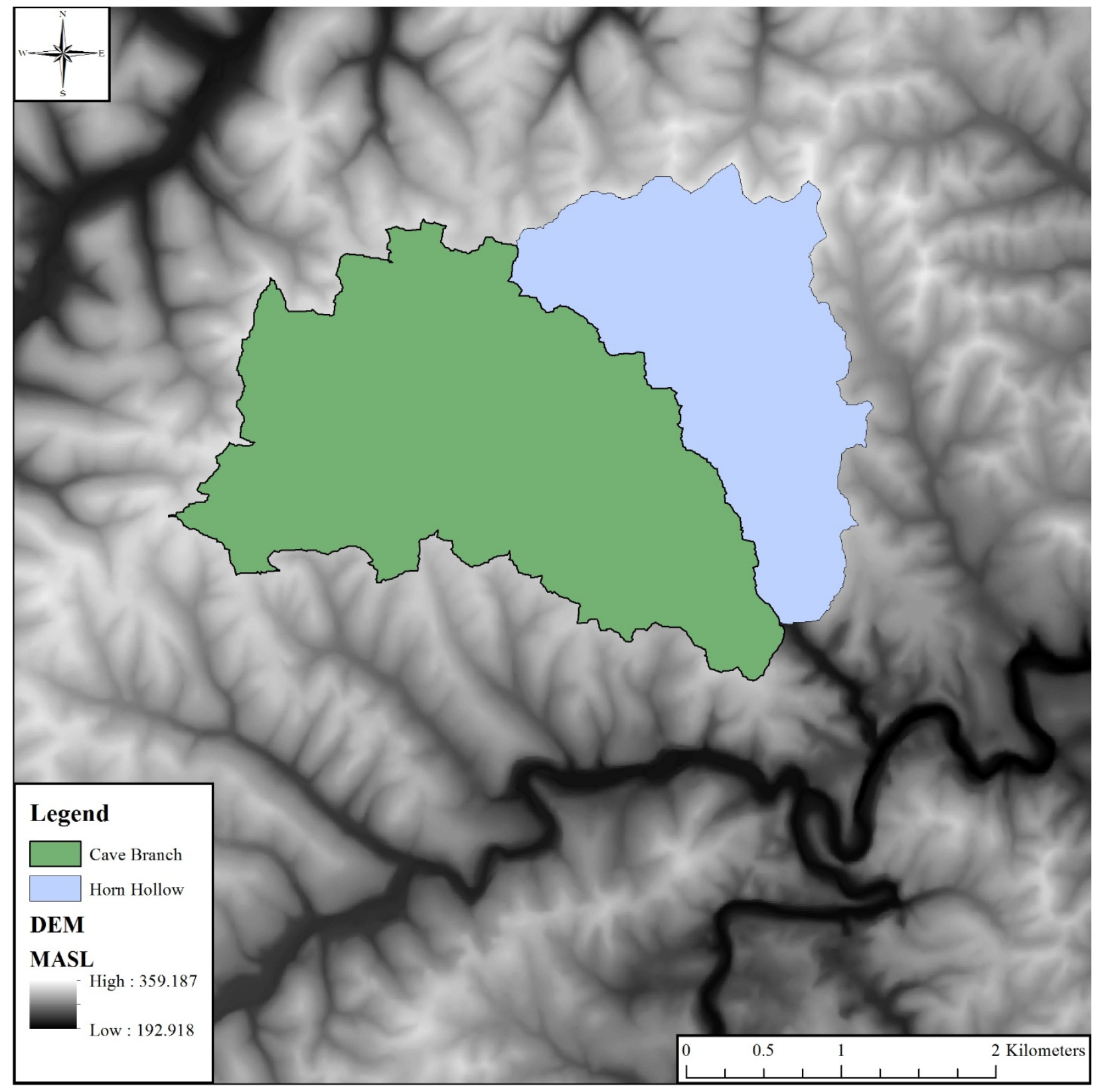

Figure 6. Cave Branch and Horn Hollow watershed 


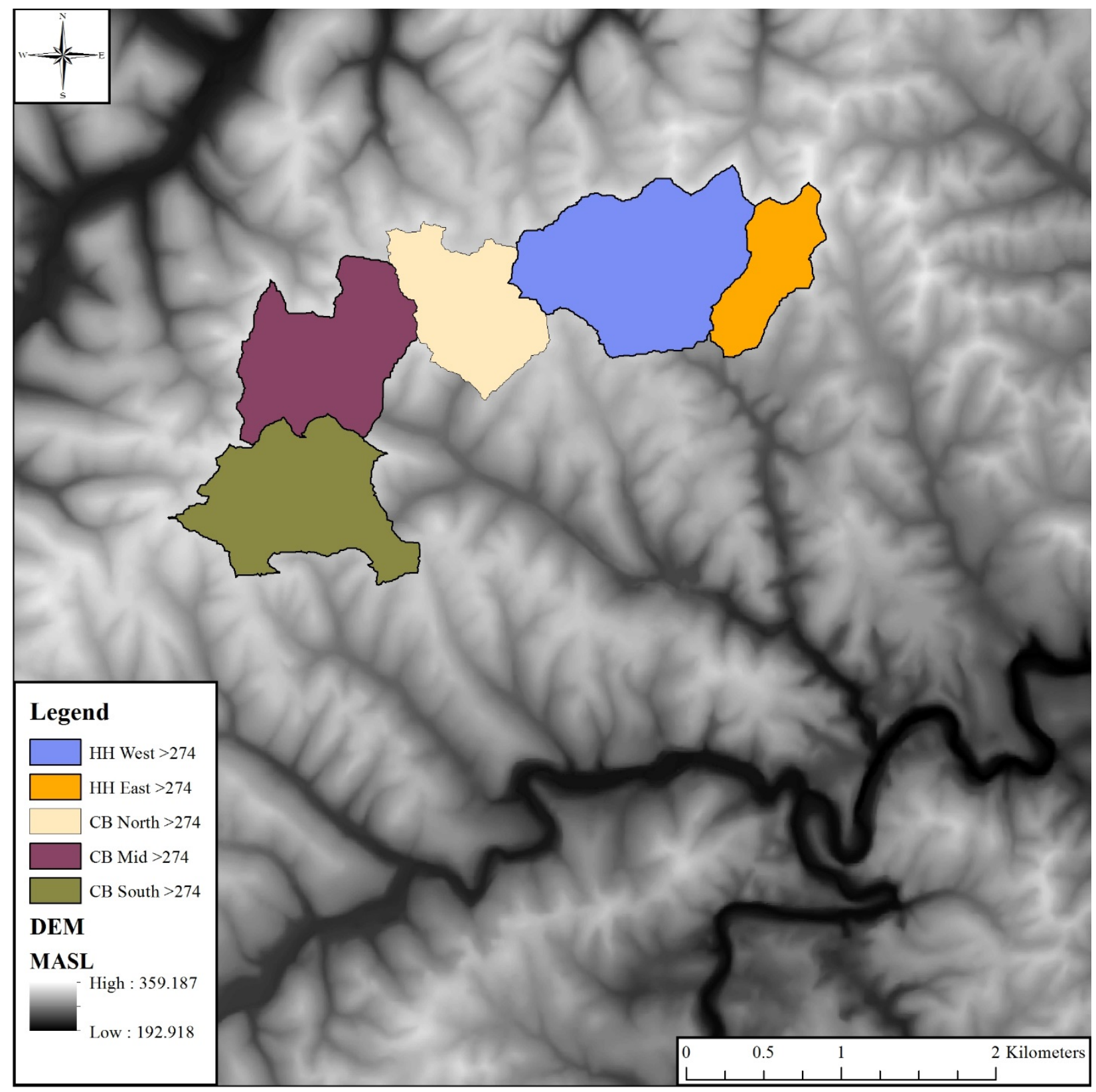

Figure 7. Sub-watersheds for Cave Branch and Horn Hollow above 274 MASL.

\section{MATLAB}

The individual watersheds were exported to and analyzed in MATLAB using the Topotoolbox (Schwanghart and Scherler 2014) and Image Processing Toolbox (MATLAB). The entire process is represented in the flow chart (Figure 8). 


\section{Convert DEM to TIF}

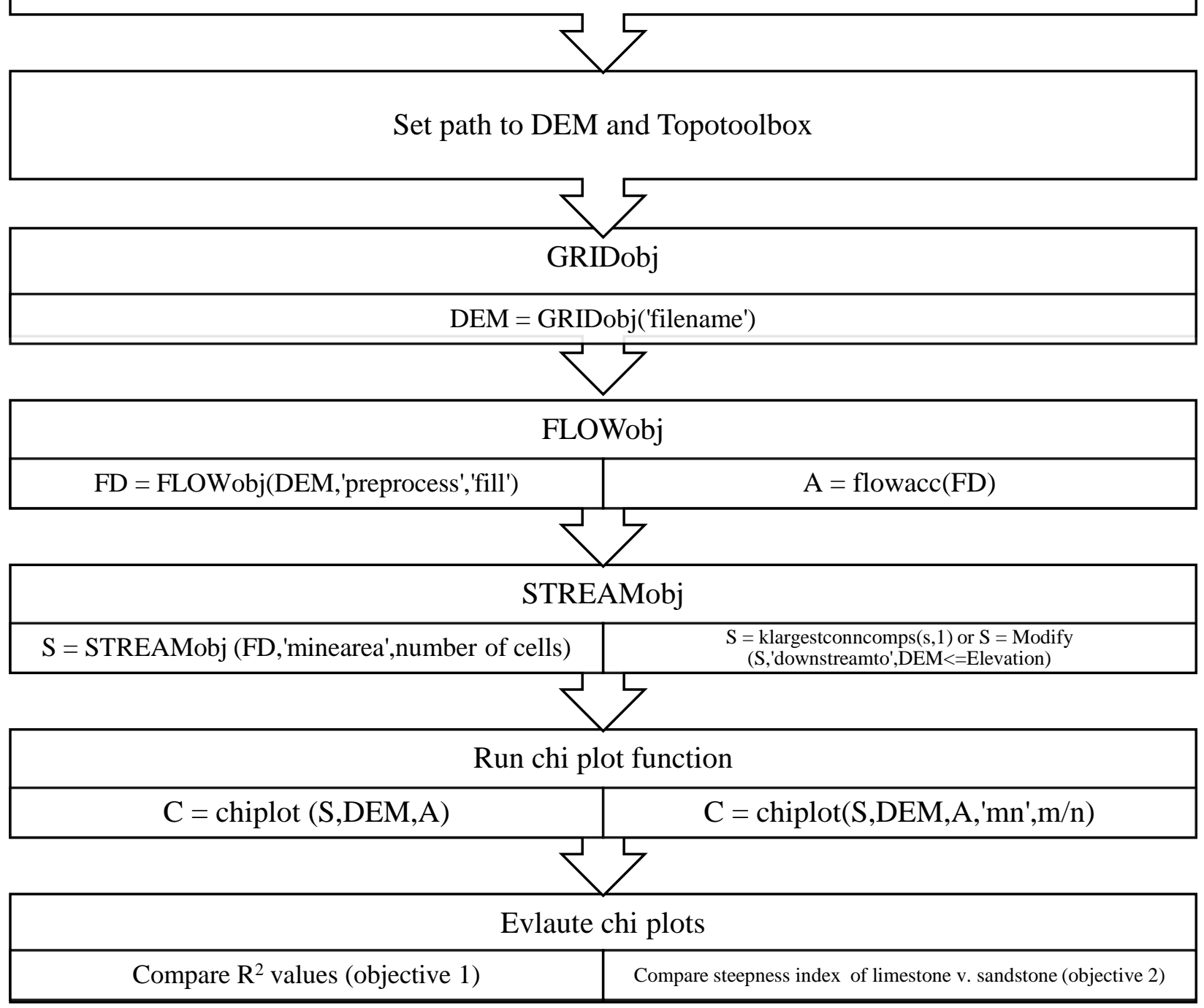

Figure 8. Outline for chi plot analysis in MATLAB.

The first step occurs before the watershed DEM is imported into MATLAB. The DEM must be converted into a TIF in GIS. To analyze the watershed in MATLAB, a stream network must be recreated using a process called object oriented programming (OOP). The stream network must be recreated because it is not carried over from GIS. Using OOP, three classes of information are created based on the DEM. The three classes of information create a stream 
network similar to the process used in GIS and are applied in the following order: GRIDobj, FLOWobj, and STREAMobj. The last class of information, STREAMobj, creates the stream network. Using this step, the flow accumulation size that determines what qualifies as a stream is established, and it allows for the stream network to be modified.

An important aspect of the flow accumulation size is to determine where the transition from colluvial to fluvial occurs. While the transition typically occurs between $10^{5}$ and $10^{6} \mathrm{~m}^{2}$, the transition for a given watershed can be determined by plotting drainage area against slope. The inflection in this graph represents where the transition from colluvial to fluvial occurs (Montgomery and Bluffington, 1997). For the entire Cave Branch watershed, including Horn Hollow, the log of drainage area and the of log slope were plotted against each other. The point along the $\mathrm{x}$-axis (drainage area) where the inflection occurs represents the drainage area that was used for the stream networks to be analyzed by the integral method via chi plots. We then modified the stream network to include areas above and below a certain elevation, and determine how the $\mathrm{m} / \mathrm{n}$ is selected.

To determine if variation in lithology was creating a state of disequilibrium within the fluviokarst system, we compared the profiles of the sandstone segments above 274 MASL and the limestone segments below 274 MASL to the individual Cave Branch and Horn Hollow watersheds. To create the chi plots for all of Cave Branch and Horn Hollow, the chi plot function in the Topotoolbox was run to include all streams above the confluence of the two streams. To create the chi plots for limestone segments, we ran the chi plot function to only include streams below 274 MASL. To create the chi plots for the sandstone streams, the upstream watersheds had to be created because an individual chi plot requires that streams drain 
to one point. The five upstream watersheds (Figure 6) were analyzed using the chi plot function including all streams above their pour point.

Before calculating the degree of equilibrium of watersheds or steepness index of streams, the $\mathrm{m} / \mathrm{n}$ ratio must be determined. To reiterate, the $\mathrm{m} / \mathrm{n}$ ratio represents the concavity of a stream. The $\mathrm{m} / \mathrm{n}$ ratio used for a given chi plot can established in one of two ways. The first way is to exclude the input value when running the chi plot, which is what is used to determine if variation in lithology was creating a state of disequilibrium. When this course of action is taken, the $\mathrm{m} / \mathrm{n}$ ratio will automatically be determined by the Topotoolbox by running a linear least-squares regression. The $m / n$ ratio that gives the greatest $R^{2}$ value will then be used. The $R^{2}$ value represents the degree of equilibrium for a watershed. As previous discussed, the chi plot method scales erosion with drainage area. Therefore, the main stem and tributaries should have almost the same slope in a chi plot. The higher the $\mathrm{R}^{2}$ value, measured on a scale from 0 to 1 , the more streams that conform the same slope. A system completely in equilibrium will have a $\mathrm{R}^{2}$ of 1 . We then compared the limestone streams and the sandstone streams to entire watersheds to see if there was a difference in the degree of equilibrium as a result of varying lithology.

To determine whether either the limestone or sandstone is more resistant to erosion (thus, having a greater SI) chi plots were analyzed in a different manner. First, subwatersheds were generated based solely on the lithology. The four watersheds with sandstone stream segments were compared to the two with limestone stream segments (Figure 9). Upstream sandstone watersheds were determined by placing pour points above 274 MASL. The downstream limestone watersheds were created from the Cave Branch and Horn Hollow watersheds, only including streams below 274 MASL. Second, the $\mathrm{m} / \mathrm{n}$ ratio was entered manually when running 
the chi plots. Finally, instead the of comparing the chi plots of watersheds in terms of $\mathrm{R}^{2}$, the chi plots of individual limestone and sandstone streams were compared in terms of their SI.

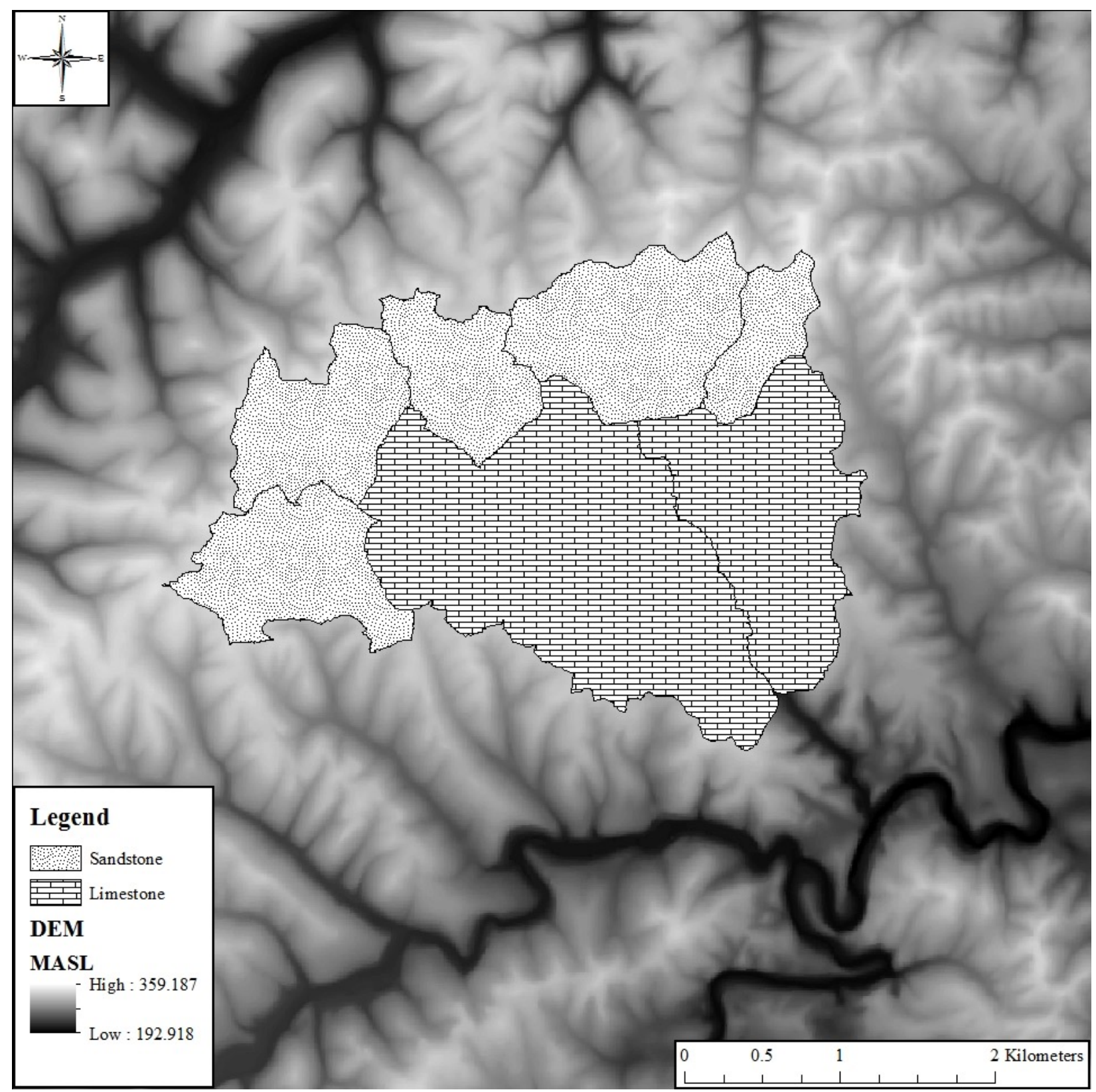

Figure 9. Individual watersheds with corresponding lithology. Limestone below 274 MASL, sandstone above 274 MASL. 
To compare the SI of different streams, limestone against sandstone, the same $\mathrm{m} / \mathrm{n}$ ratio must be used. The $\mathrm{m} / \mathrm{n}$ ratio to be used was determined with a sensitivity analysis. A sensitivity analysis was run for each watershed to determine the $\mathrm{m} / \mathrm{n}$ ratio that yielded the lowest $\mathrm{R}^{2}$ value. A range of 0.1-0.9 was used to in the sensitivity analysis, which was used because bedrock streams typically have an $\mathrm{m} / \mathrm{n}$ ratio of 0.2 to 0.6 (Whipple and Tucker 1999). Using the same $\mathrm{m} / \mathrm{n}$, chi plots were generated for each of the watersheds. Data for individual streams were taken from MATLAB and plotted in Excel. Once the SI of each individual limestone and sandstone streams were established, the values were evaluated with at t-test to determine if there was a statistical difference between the limestone and sandstone streams. 


\section{CHAPTER III}

\section{RESULTS}

Before creating chi plots, the proper flow accumulation size needed to be determined. This was accomplished by creating a log-log plot of drainage area against slope for streams within the watersheds (Figure 10). The infection of the drainage area-slope graph, which signifies the transition from colluvial to fluvial occurs around $10^{5.98} \mathrm{~m}^{2}$. Only streams with a drainage area greater than this value were used in the chi plot calculations. 


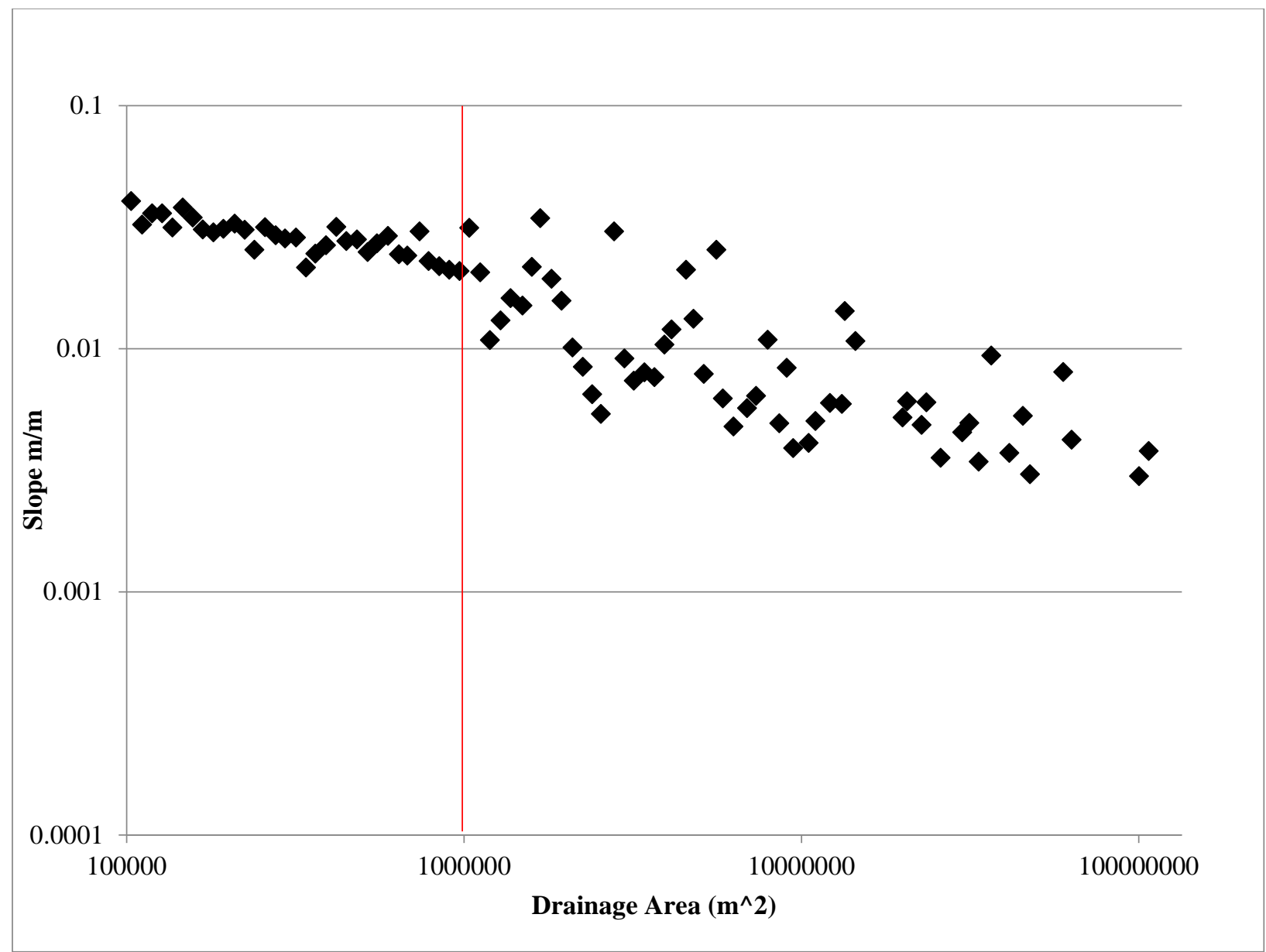

Figure 10. Log-log drainage area-slope plot used to determine the flow accumulation that constituted a stream in the Cave Branch Basin. The inflection occurs at $10^{5.98} \mathbf{m}^{2}$

\section{Equilibrium Analysis}

The analyses provided chi plot results for the Cave Branch and Horn Hollow watersheds along with the sub watersheds in each Table (1). 
Table 1. Results from equilibrium analysis. SS represents sandstone and LS represents limestone.

\begin{tabular}{|lrr|}
\hline Watershed & $\mathrm{m} / \mathrm{n}$ & \multicolumn{2}{c|}{$\mathrm{R}^{2}$} \\
\hline \hline Cave Branch (SS\&LS) & 0.276 & 0.8008 \\
CBless274 (LS) & 0.502 & 0.859 \\
CB274south (SS) & 0.5536 & 0.977 \\
CB274north (SS) & -0.599 & 0.79 \\
CB274mid (SS) & 0.6461 & 0.9381 \\
\hline Horn Hollow (SS\&LS) & 0.05 & 0.923 \\
HHless274 (LS) & 0.543 & 0.7978 \\
HH274east (SS) & -1.724 & 0.8557 \\
HH274west (SS) & -0.093 & 0.8595 \\
\hline
\end{tabular}

The results of the equilibrium analysis revealed that the entire Horn Hollow watershed had a greater $\mathrm{R}^{2}$ than its subwatersheds, and the entire Cave Branch had a lower $\mathrm{R}^{2}$ than its subwatersheds. For both Cave Branch and Horn Hollow, the sandstone segments exhibit a greater $\mathrm{R}^{2}$ than the limestone segments. The $\mathrm{m} / \mathrm{n}$ values for Horn Hollow and its subwatersheds ranged from -0.59 to 0.64 . The $\mathrm{m} / \mathrm{n}$ values for Cave Branch and its subwatersheds ranged from -1.724 to 0.543 . A positive $\mathrm{m} / \mathrm{n}$ represents a stream with a concave-up, while a negative $\mathrm{m} / \mathrm{n}$ represents a concave-down stream profile. Both watersheds exhibited a range of $\mathrm{m} / \mathrm{n}$ ratios, but the $\mathrm{m} / \mathrm{n}$ ratio of the entire Horn Hollow and Cave Branch watersheds differed by an order of magnitude. The chi plots of the individual watersheds can be seen in Figures 11-19. The more collinear the chi plot, the higher the $\mathrm{R}^{2}$. Slope of chi plot represent the SI. 


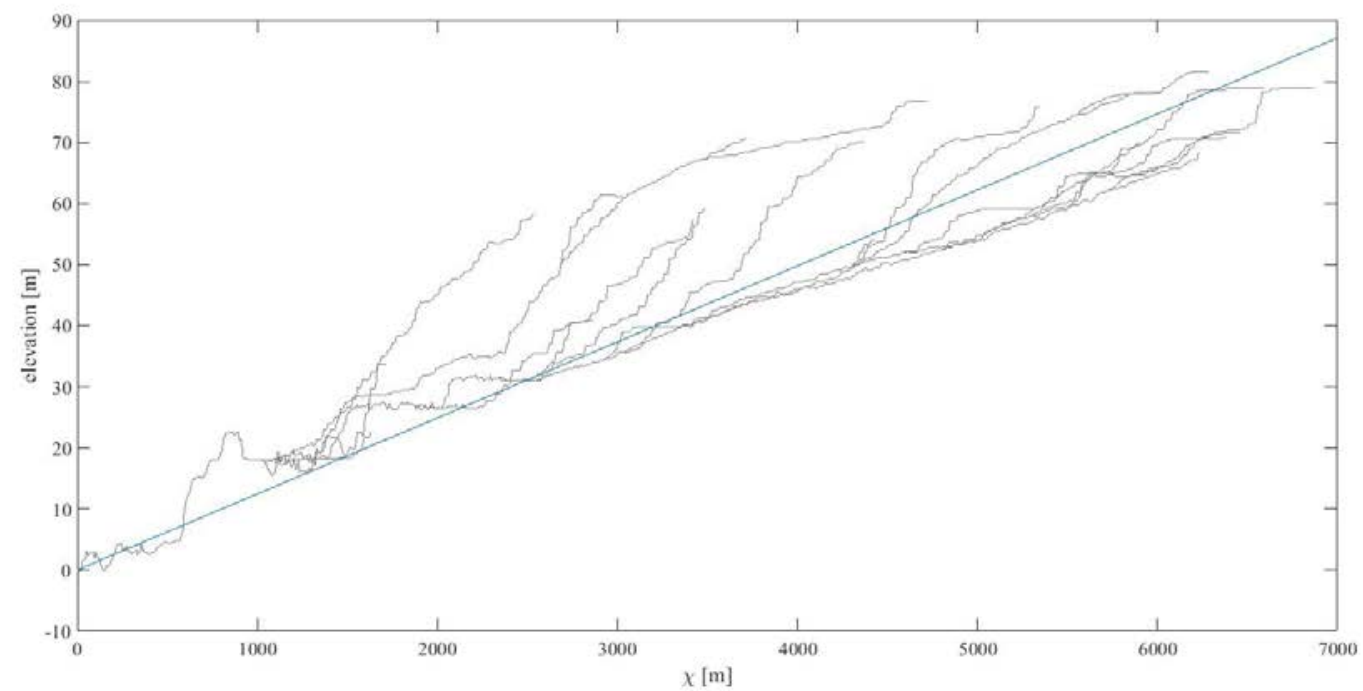

Figure 11. Cave Branch chi plot, including sandstone and limestone segments. Gray lines represent chi plot individual streams and the blue line represents best fit for the watershed.

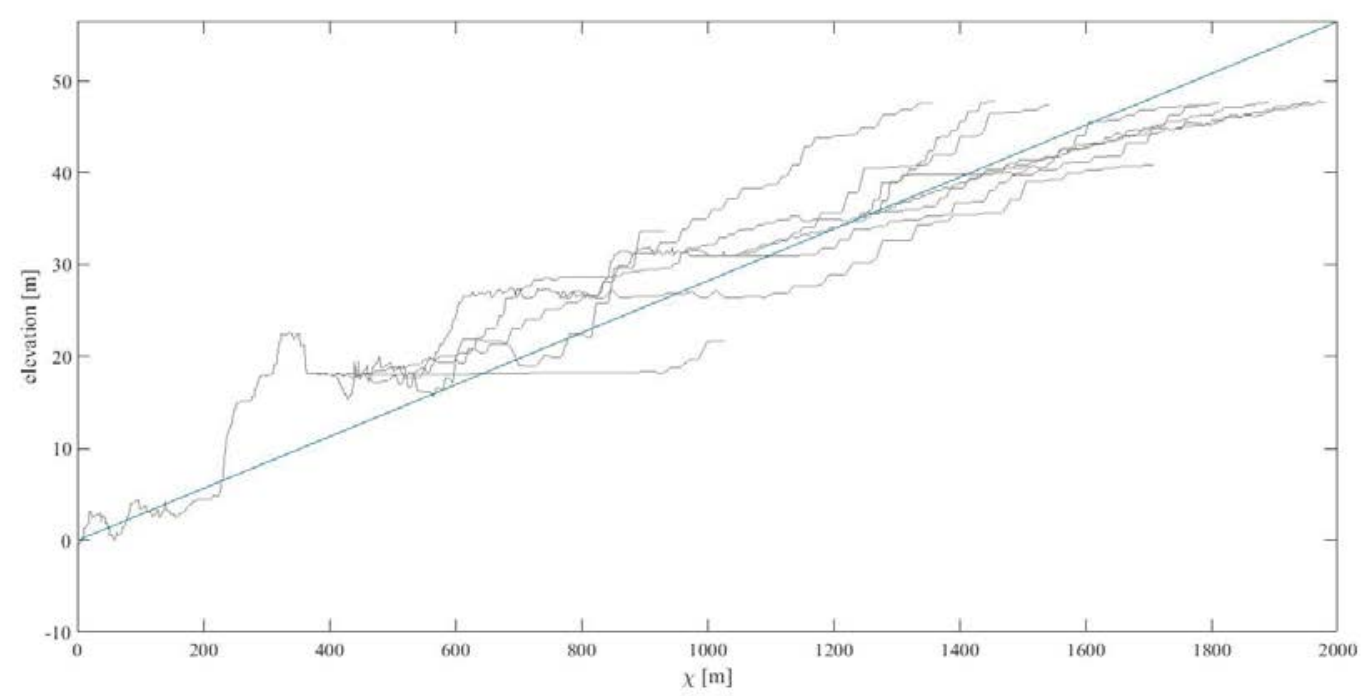

Figure 12. CB<274, Cave Branch streams below 274 MASL, limestone streams. 


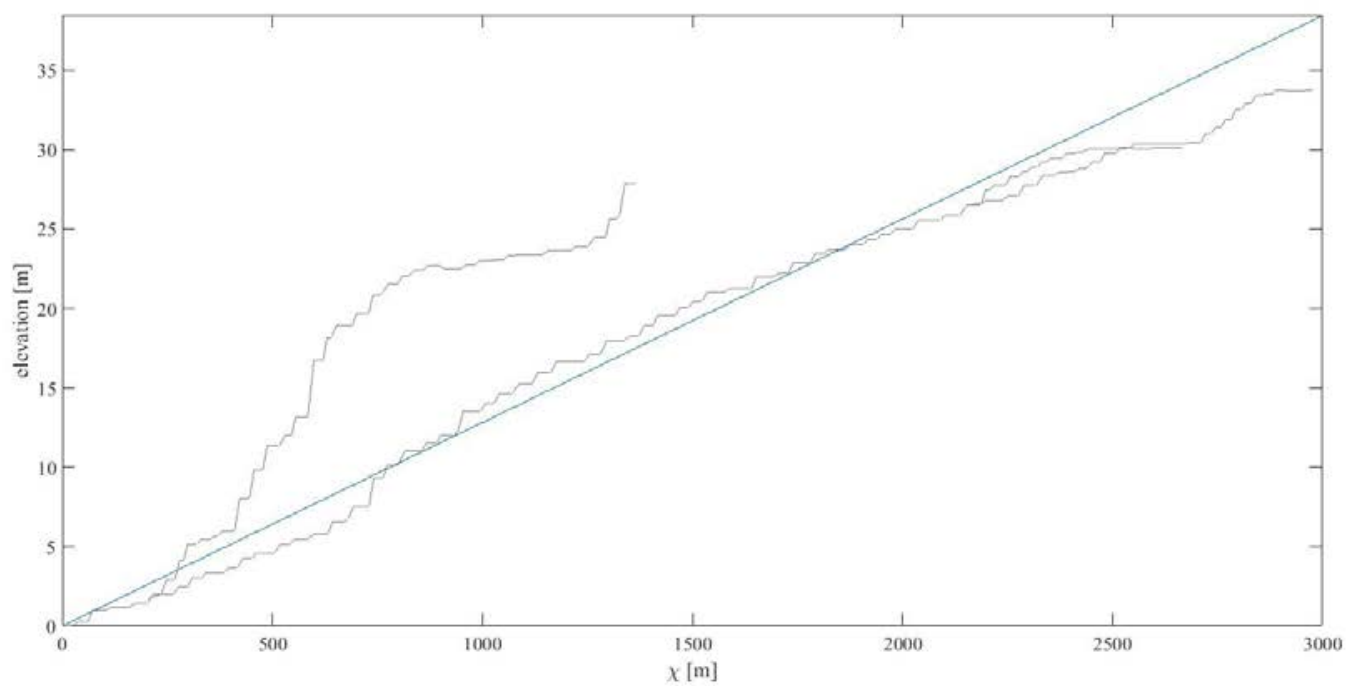

Figure 13. CB274North, Cave Branch chi plot above 274 MASL, sandstone streams.

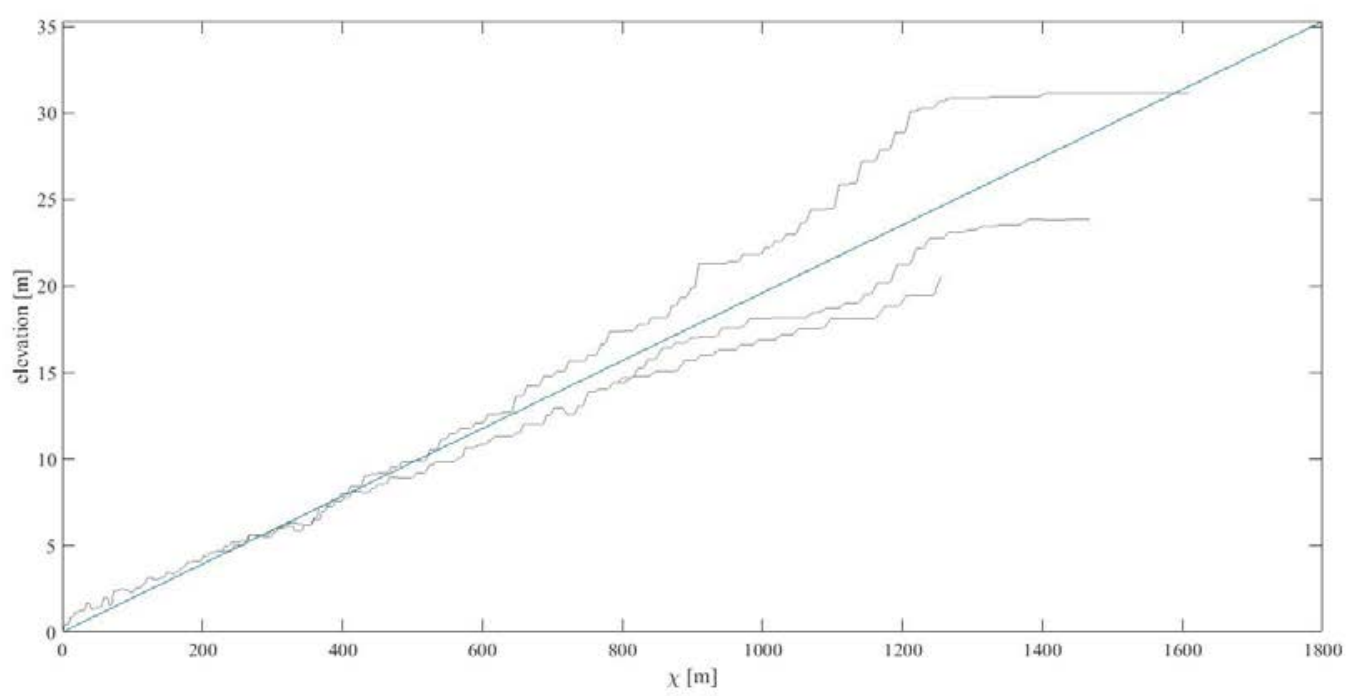

Figure 14. CBMid274, Cave Branch chi plot above 274 MASL, sandstone streams. 


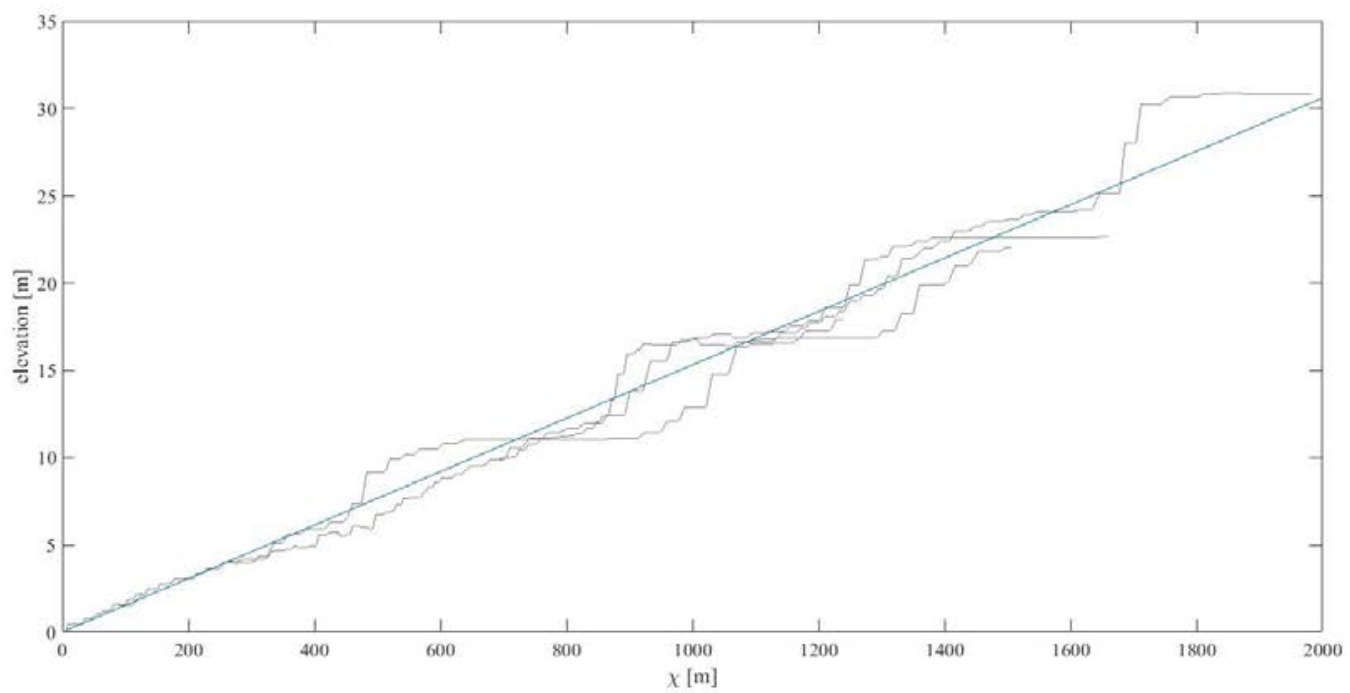

Figure 15. CBSouth274, Cave Branch chi plot above 274 MASL, sandstone streams.

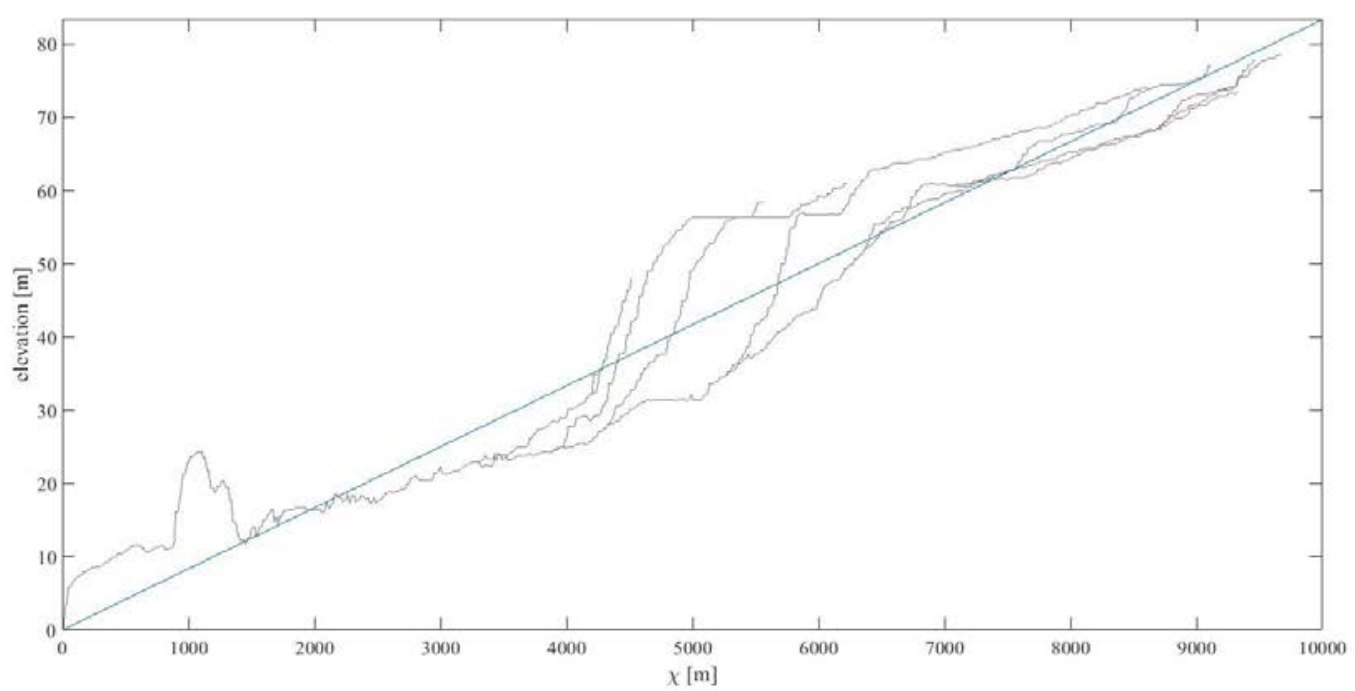

Figure 16. Horn Hollow chi plot including sandstone and limestone streams. 


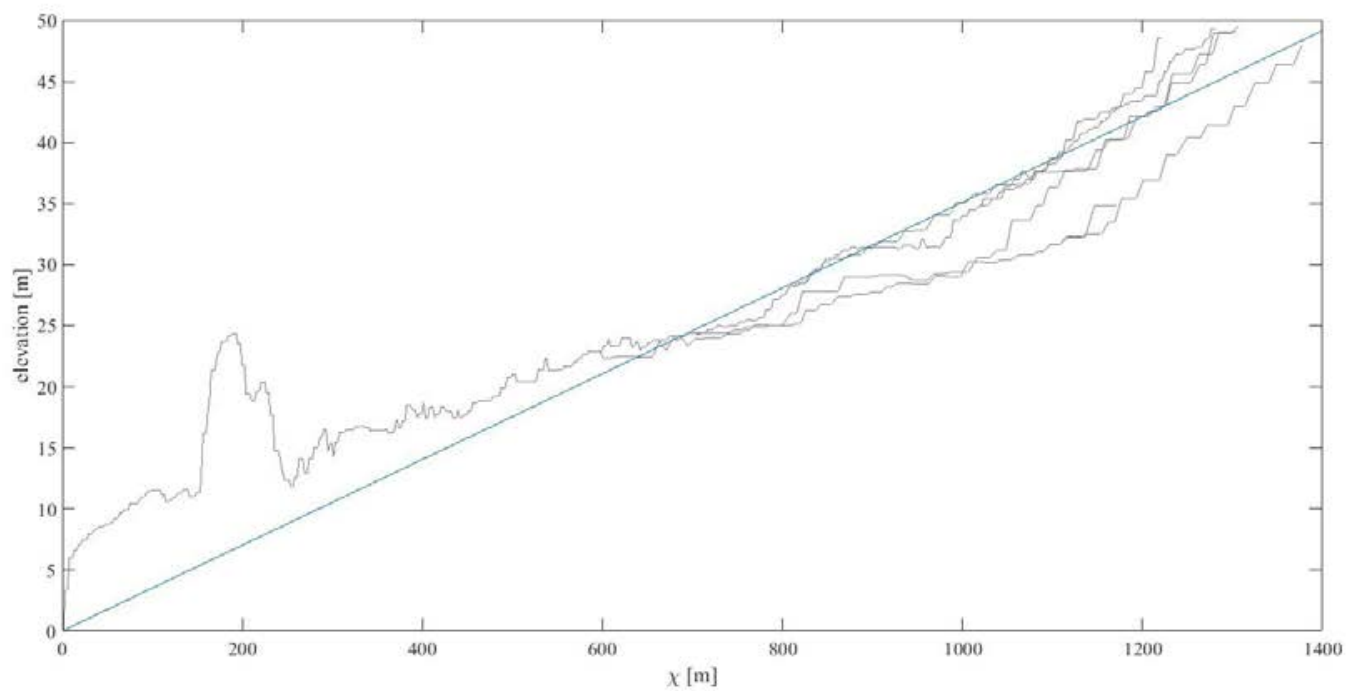

Figure 17. HH<274, Horn Hollow chi plot below 274 MASL, limestone streams.

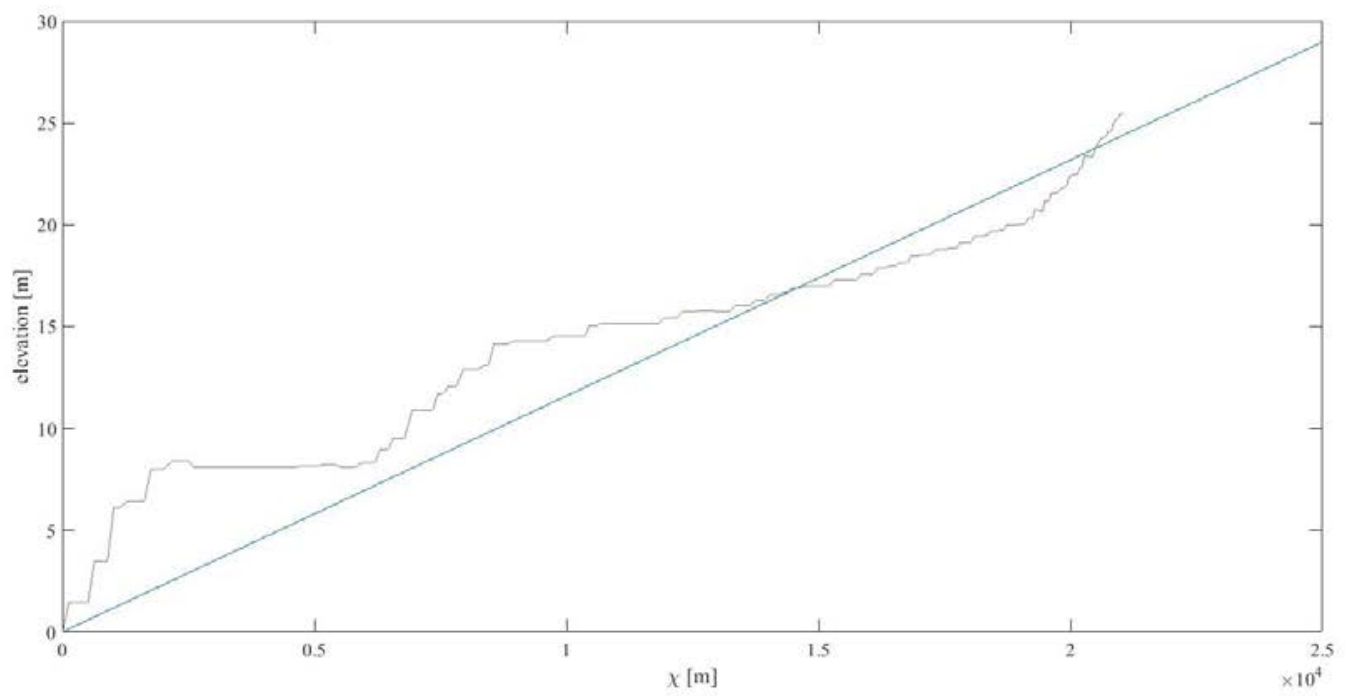

Figure 18. HH274East, Horn Hollow chi plot above 274 MASL, sandstone streams. 


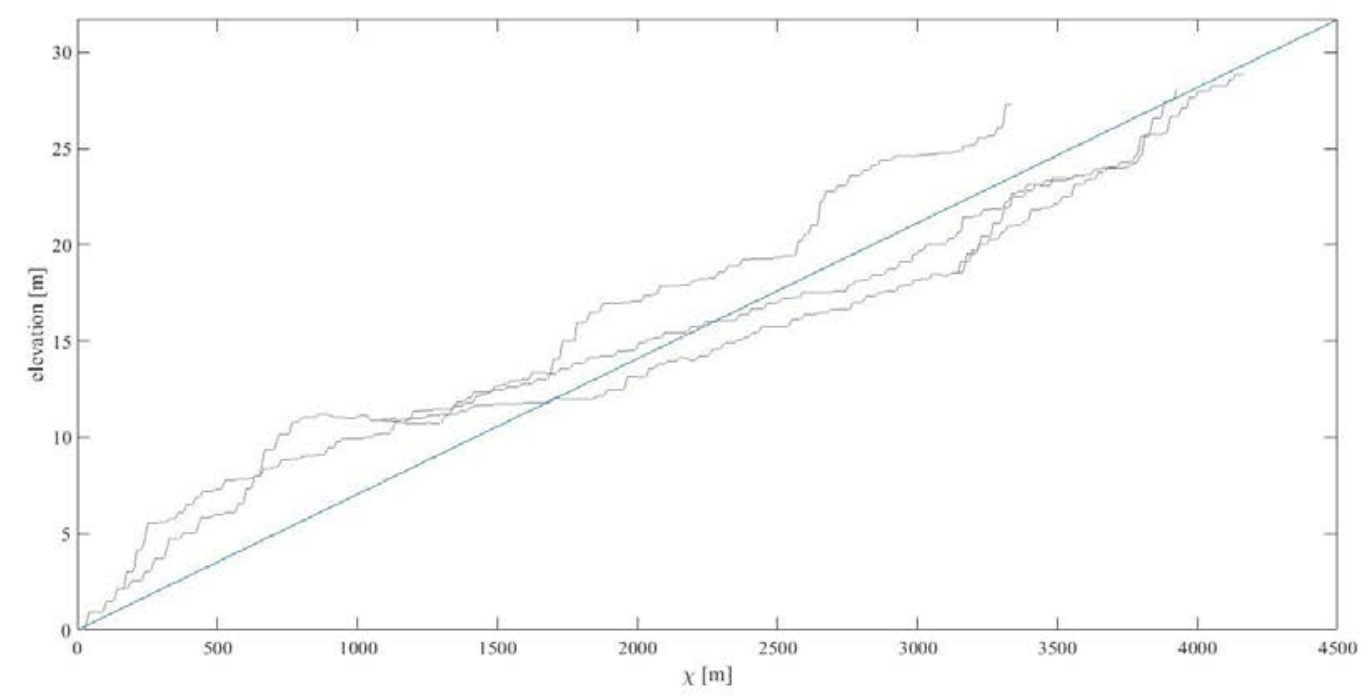

Figure 19. HH274West, Horn Hollow chi plot above 274 MASL, sandstone streams.

\section{Sensitivity Analysis}

The sensitivity analysis was conducted by running a chi plot for the entire Cave Branch watershed, including Horn Hollow which used manually entered $\mathrm{m} / \mathrm{n}$ ratios by the user. Values from 0.1 to 0.9 were used to determine which yielded the highest $\mathrm{R}^{2}$ value (Table 2). The $\mathrm{m} / \mathrm{n}$ value of 0.4 generated the highest $\mathrm{R}^{2}$ value, making it the most representative of the entire watershed. This value of 0.4 was used when chi plots were created to compare the SI of sandstone and limestone streams, falling within the range of values produced from the equilibrium analysis using a least square regression. There were a range of $\mathrm{m} / \mathrm{n}$ ratio generated from the equilibrium, including both positive and negative values suggesting concave-up and concave-down stream profiles respectively. The positive value for the entire Cave Branch watershed, including Horn Hollow, suggest overall the system consists of concave-up stream profiles. 


\section{Table 2. Sensitivity analysis of $\mathrm{m} / \mathrm{n}$ ratio for the Cave Branch Basin.}

\begin{tabular}{|r|c|r|}
\hline \multicolumn{1}{|c|}{$\mathrm{m} / \mathrm{n}$} & $\mathrm{R}^{2}$ & \multicolumn{1}{|c|}{$\begin{array}{c}\text { Steepness } \\
\text { index }\end{array}$} \\
\hline 0.1 & 0.7643 & 0.0076 \\
0.2 & 0.7993 & 0.0107 \\
0.3 & 0.8224 & 0.015 \\
0.4 & 0.8262 & 0.0207 \\
0.5 & 0.8015 & 0.0279 \\
0.6 & 0.7385 & 0.0369 \\
0.7 & 0.6286 & 0.0475 \\
0.8 & 0.4667 & 0.595 \\
0.9 & 0.253 & 0.0726 \\
\hline
\end{tabular}

\section{Steepness Index (SI) Analysis}

Upon identifying a $\mathrm{m} / \mathrm{n}$ ratio of 0.4 , individual chi plots for the limestone and sandstone watersheds were generated chi plots for 17 limestone streams and 16 sandstone streams provided SI values for comparison. The mean SI for the streams with limestone bedrock was 0.026 with a variance of $2.0 \times 10^{-4}$; for the sandstone hosted streams, the mean SI was 0.013 with a variance of $2.2 \times 10^{-5}$. This suggests that the limestone streams are more resistant, and there less consistency in the resistance of limestone streams. A t-test was performed, using an alpha value of 0.05 , to see if there was a statistical difference between the two lithologies and p-value of 0.0007 suggests that there is a statistical difference between the limestone and sandstone streams. The box plot of the SI values for sandstone and limestone streams can be seen in Figure 20. 


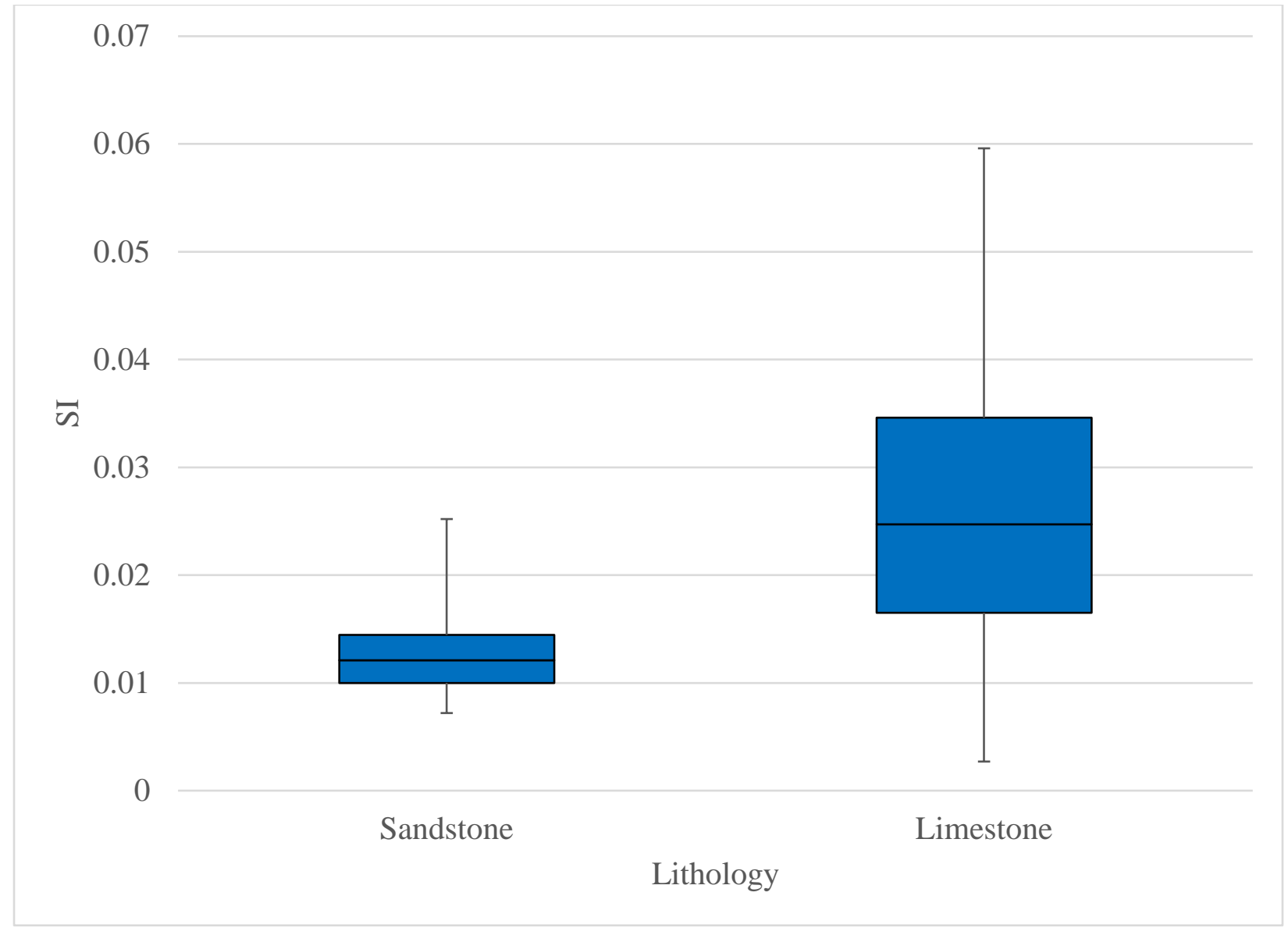

Figure 20. Box plot of SI values of sandstone and limestone streams. 


\section{CHAPTER IV}

\section{DISCUSSION}

The first objective of this study was to determine whether lithology was responsible for a state of disequilibrium. The results of the equilibrium analysis revealed that the degree of equilibrium varied from the sandstone to the limestone sections of Cave Branch and Horn Hollow. All the factors that can affect the shape of a profile, which include climate, tectonics, changes in base level, are held constant except for variation in lithology. The results of the equilibrium analysis revealed that the sandstone watersheds were generally in a greater degree of equilibrium than the limestone. The variation in $\mathrm{m} / \mathrm{n}$ suggest that the system as a whole is in a state of disequilibrium. This assessment is illustrated in the chi plot of the entire Horn Hollow watershed (Figure 21). At the contact of sandstone and limestone (red line on the diagram), the Horn Hollow chi plot displays a drastic change in slope, or SI. The second objective was to determine whether the sandstone or limestone streams was more resistant based on SI. Performing chi plots on individual sandstone and limestone streams, and evaluating those results with a t-test, revealed that there is a statistical difference between sandstone and limestone, and that limestone streams have a greater SI. The third objective was to determine how variation in lithology was effecting the development of this fluviokarst system. The conclusion of the third objective is the interpretation of the chi plot data in conjunction with findings from previous investigations. 
The results of the equilibrium analysis show that the sandstone watersheds generally have a greater $\mathrm{R}^{2}$ value than the limestone watersheds. The first objective was to determine whether variation in lithology was creating a state of disequilibrium within the entire Cave Branch and Horn Hollow watershed. Based on the $\mathrm{R}^{2}$ values alone, the results are inconclusive. While the individual sandstone and limestone streams were different in the degree of equilibrium, the Horn Hollow watershed as a whole was in a greater state of equilibrium than the individual subwatersheds. The entire Cave Branch watershed had a lower degree of equilibrium than 3 of its 4 sub-watersheds. The extract reason for this difference is unknown and will require further investigation. One chi plot did represent a drastic change from sandstone to limestone. Qualitatively, there is an abrupt change in the chi plot Horn Hollow (Figure 21). In the chi plot of the entire Horn Hollow watershed, there is a drastic change in the slope of transformed stream profile. It appears that the upstream sandstone segment is equilibrium, while the downstream segments appear to be in a state of disequilibrium, with a greater SI. 


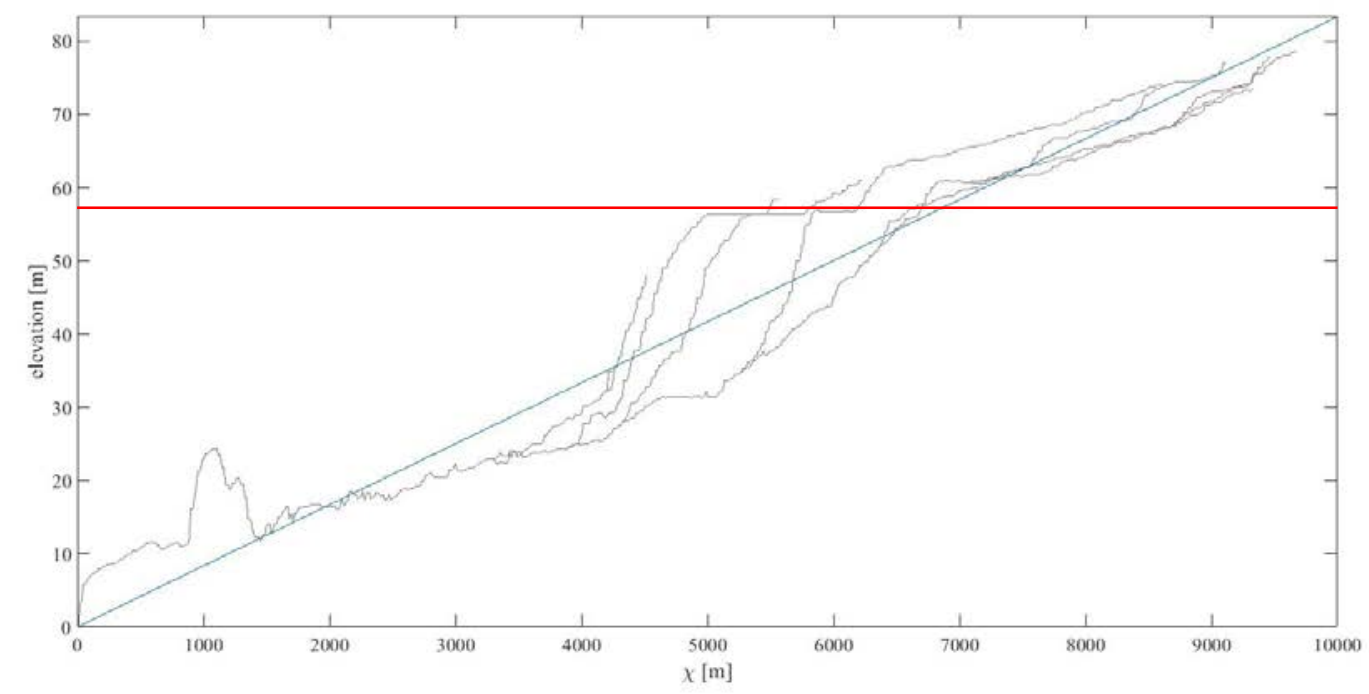

Figure 21. Chi plot of Horn Hollow. Red Line represents 274 meters above sea level, where a change in the slope, SI, occurs.

One aspect that did support the lithology creating a state of disequilibrium was the difference in $\mathrm{m} / \mathrm{n}$ values between the sandstone watersheds. In Horn Hollow, both of the sandstone watersheds had a negative $\mathrm{m} / \mathrm{n}$, and one of three Cave Branch sandstone watersheds had a negative $\mathrm{m} / \mathrm{n}$. Typically, bedrock streams have a m/n value between 0.2 to 0.6 giving a concave-up profile. A negative $\mathrm{m} / \mathrm{n}$ suggests a concave-down stream profile. The transition from concave down profiles to concave-up profiles suggest a state of disequilibrium. It should be noted that equilibrium streams typically have a concave-up profile. To better understand the relationship between $\mathrm{m} / \mathrm{n}$ and $\mathrm{R}^{2}$, further investigation will be necessary.

The second objective was to determine whether the limestone or sandstone was more resistance to erosion based on SI, for which there was a conclusive answer. Based on the results of a t-test which compared the SI of sandstone and limestone streams, limestone streams have a greater SI, and the difference in statistically significant. On the surface, the greater SI of 
limestone streams would suggest that limestone in the Carter Caves area is more resistant than the sandstone. This is a possible explanation, but not necessarily the case when all variables are considered.

One explanation for the different observed SI in the sandstones and limestone is the difference in weathering processes. As previously stated, sandstones are subjected to physical weathering, and limestone can be weathered by physical and chemical processes. In the limestone segments, streams can be diverted to the subsurface. The reason streams are diverted into the subsurface in a specific location is that water moving from a sandstone to a limestone is going to be more aggressive, having yet to be neutralized (Bogli, 1964). The more aggressive water is likely to encourage dissolution and subsurface piracy, once in contact with soluble limestone. Once in the subsurface, the stream maintains an equilibrium profile, leaving a 'bump' in the profile where erosion is not occurring (White and White, 1983, Woodside et al., 2015).

Furthermore, the difference in SI between limestone and sandstone streams could be due to the continued denudation in the limestone areas of Cave Branch and Horn Hollow. As streams in the limestone sections are diverted into the subsurface, the continued denudation in the subsurface increased the gradient between tributary and main stem. Woodside et al. (2015) observed evidence of cave collapse in Horn Hollow. Instead of the typical v-shaped valley that develop in bedrock streams, Horn Hollow displayed vertical valley walls in areas. In areas where cave collapse has occurred, the steeper gradient is exposed to the surface. The existence of cave collapse would also explain the greater degree of equilibrium observed in the sandstone watersheds.

The third objective was to determine how erosional differences in the limestone and sandstone are related to the overall development. To answer this question, the assessments made 
from the first and second objectives must be considered concurrently. The greater degree of equilibrium in the sandstone watersheds and the greater steepness in the limestone streams is a function of both the soluble nature of limestone and the glacial-fluvial development of northeastern Kentucky. The rapid development of the fluviokarst system in northeastern Kentucky lead to the development of 4 distinct cave level (Jacoby et al. 2013). The caves in the Horn Hollow and Cave Branch represent the levels of cave development linked to a common static base level. During these periods of stable base level, streams in the limestone segments were diverted to the subsurface. While in the subsurface, these limestone streams maintain their equilibrium profile (White and White, 1983, Woodside et al., 2015). Overtime, a subterranean stream can be exposed to the surface because of cave collapse. Woodside et al. (2015) saw evidence of Cave Collapse in Horn Hollow Creek. The disequilibrium in the limestone sections of Horn Hollow and Cave Branch is the result of cave collapse. As cave collapse occurs the disequilibrium that exists between main stem and ephemeral tributary is exposed to the surface. The greater SI in the limestone streams is a result of the subsurface piracy and eventual cave collapse. As the main stem continued to denudate in the subsurface, the gradient between it and the tributaries increased. The sandstone streams, which generally had a greater degree of equilibrium had started to develop prior to glaciation when the system was a part of the Teays drainage system (Tierney, 1985).

Schroeder (2014) conducted a study on a fluviokarst system in southeastern Minnesota, where anomalous segments were not present in the limestone streams. The difference between the fluviokarst system in southeastern Minnesota and the one in northeastern Kentucky was that glacial-fluvial influence. This suggests that rapid development of the fluviokarst system, caused 
by glacial and interglacial periods, has created the anomalous sections and the difference in equilibrium between the limestone and sandstone watersheds. 


\section{CHAPTER V}

\section{CONCLUSION}

The purpose of this study was to determine how the variation in lithology was influencing the development of the fluviokarst system in CCSRP in northeastern Kentucky. To do this, streams were compared using a equation that calculates stream power and allows for the degree of equilibrium of watersheds and SI values of streams to be compared. Using this method, the watersheds and individual streams of Cave Branch and Horn Hollow watershedds were analyzed. It was determined that sandstone watersheds were generally in a greater degree of equilibrium than the limestone watersheds, and that the limestone streams had a greater SI. SI is a measure of a streams resistance to erosion, but when the differences in weathering processes in limstone and sandstone are considered, SI reveals more than just resistance to erosion. The soluble nature of limestone lends its self the development of karst, while sandstone is eroded only by physical processes. Also, the difference between the limestone and sandstone segements is due to the rapid development influeced by glacial and interglacial periods. The glacial-fluvial influence explains the difference between the fluviokarst system in northeastern Kentukcy and the one in southeastern Minnesota.

One uncertainty that remains from this study were the results of the equilibrium analysis. While there was generally a greater degree of equilibrium in the sandstone watersheds than in the limestone watersehds, the entire Horn Hollow watershed had a greater degree of equilibrium than all of its sub-watersheds. In contrast, the entire Cave Branch watershed had a lower $\mathrm{R}^{2}$ than three 
of its four sub-watersheds. While the $\mathrm{R}^{2}$ values indicated that the entire Horn Hollow watershed was in a greater state of equilibrium than its subwatersheds, the transition from concave-down stream profiles to concave-up, suggetsts that as a whole the system is in a state of disequilibrium. To better understand the results of the equilibrium analysis, further investigation will be nessessary to understand the difference and the significance of $\mathrm{R}^{2}$ and the application of $\mathrm{m} / \mathrm{n}$. This would allow for a better understanding of the differences between Cave Branch and Horn Hollow.

It would also be helpful to apply the method used in this study to the fluviokarst system in southeastern Minnesota. While it has been established that streams in this system did not display anamolus bumps de to subsurface piracy, looking at the degree of equilibrium of limestone and sandstone watersheds anc comparing the SI values could provide further insite into the development of this system. 


\section{REFERENCES}

Anthony, D.M., Granger, D.E., 2004, A late Tertiary origin for multilevel caves along the western escarpment of the Cumberland Plateau, Tennessee and Kentucky, Established by Cosmogenic ${ }^{26} \mathrm{Al}$ and ${ }^{10} \mathrm{Be}$ : Journal of Cave and Karst Studies, vol. 66, no. 2, p. 46-55.

Anthony, D.M., Granger, D.E., 2007, An empirical stream power formulation for knickpoint retreat in Appalachian Plateau fluviokarst: Journal of Hydrology, vol. 343, p. 117-126, doi:10.1016/j.jhydrol.2007.06.013.

Bocic, N., 2003, Relation between Karst and Fluviokarst relief on the Slunj Plateau (Croatia): Acta Carsologica, vol. 32, no. 2 p. 137-146.

Bogli, A., 1964, Corrosion by mixing of waters: International Journal of Speleology, vol. 1, pg. 61-70.

Dogwiler, T., and Wicks, C.M., 2004, Sediment entrainment and transport in fluviokarst systems: Journal of Hydrology, vol. 295, p. 163-172, doi: 10.1016/j.jhydrol.2004.03.002.

Engel, A.S., and Engel, S.A., 2009, A field guide for the karst of Carter Caves State Resort Park and the surrounding area, northeastern Kentucky, Select field guides to caves and karst lands of the United States. Special Publication 15: Leesburg, Virginia, Karst Waters Institute, Inc., p. 81-99.

Goldrick, G., Bishop, P., 2007, Regional analysis of bedrock stream long profiles: evaluations of Hack's SL form, and formulation and assessment of an alternative (the DS form): Earth Surface Processes and Landforms, vol. 32, pg. 649-671, doi: 10.1002/esp.1413.

Hack, J. T. 1957, Studies of longitudinal stream profiles in Virginia and Maryland: U.S. Geological Survey Prof. Paper 294-B, p. 45-97.

Hack, J.T., 1973, Stream-profile analysis and stream-gradient index: Journal of Research of the U.S. Geological Survey, vol. 4, pg. 421-429.

Jacoby, B.S., Peterson, E.W., and Dogwiler, T., 2011, Identifying the stream erosion potential of cave levels in Carter Cave State Resort Park, Kentucky, USA: Journal of Geographic Information Systems, vol. 3, no. 4, p. 323-333, doi: 10.4236/jgis.2011.34030. 
Jacoby, B.S., Peterson, E.W., Kostelnick, J.C., and Dogwiler, T., 2013, Approaching cave level identification with GIS: A case study of Carter Caves: ISRN Geology, vol. 2013, p. 1-7, doi: 10.1155/2013/160397.

Jakucs, L., 1977, Morphogenetics of karst regions: variants of karst evolution: New York, John Wiles \& Sons, Inc., pg. 172-194.

Jennings, J.N., 1985, Karst geomorphology. New York: Basil Blackwell Inc.

Knighton, D., 1998, Fluvial Forms and Processes: A New Perspective: New York, John Wiley \& Sons Inc., pg. 96-242.

Mackin, J.H., 1948, Concept of the graded river: Geological society of America Bulletin, vol. 59, no. 5, p. 463-512, doi: 10.1130/0016-7606(1948)59[463:COTGR]2.0.CO;2.

Martin, J.B., White W.B., (eds.), 2008, Frontiers of karst research. Special Publication 13, Karst Waters Institute, Leesburg Virginia, pg. 1-9.

MATLAB and Image Processing Toolbox Release 2016b, The MathWorks, Inc., Natick, Massachusetts, United States.

Miller, J.R., 1991, Controls on channel form along bedrock-influenced alluvial streams in southcentral Indiana: Physical Geography., vol. 12, pg. 167-187, DOI: 10.1080/02723646.1991.10642425.

Montgomery, D.R., and Bluffington, J.M, 1997, Channel-reach morphology in mountain drainage basins, Geological Society of America Bulletin, v. 109, no. 5, p. 596-611, DOI: 10.1130/0016-7606(1997)109<0596:CRMI>2.3.CO;2

Nesbitt, H.W., Fedo, C.M., and Young, G.M., Quartz and feldspar stability, steady and nonsteady-state wreathing and petrogenesis of siliciclastics sands and muds: The Journal of Geology, vol. 105, no. 2, pg. 173-192, DOI: 10.1086/51908

Perron, J.T., and Royden, L., 2013, An integral approach to bedrock river profile analysis: Earth Surface Processes and Landforms, vol. 38, no. 6, p. 570-576, doi: 10.1002/esp.3302.

Peterson, E.W., Dogwiler, T., and Harlan, L., 2011, Using GIS to identify cave levels and discern the speleogenesis of the Carter Caves karst area, Kentucky: U.S., in U.S. Geological Survey Karst Inters Group Proceedings, Fayetteville: Arkansas, United States Geological Survey, Volume of Scientific Investigations Report, p. 94-103. 
Phillips, J.D., and Lutz, J.D., 2008, Profile convexities in bedrock and alluvial streams: Geomorphology, vol. 102, pg. 554-566, DOI: 10.1016/j.geomorph.2008.05.042.

Ritter, D.F., Kochel, R.C., and Miller, J.R., 2011, Process Geomorphology: Long Grove, Waveland Press, Inc., pg. 471-501.

Schroeder, K., 2014, Determining the source of anomalous segments in a karst stream [Master's thesis]: Normal, Illinois State University.

Schwanghart, W., and Scherler, D., 2014, Topotoolbox 2- MATLAB-based software for topographic analysis and modeling in Earth surface sciences: Earth Surface Dynamics, vol. 2, pg. 1-7, DOI: 10.5194/esurf-2-1-2014.

Sklar, L., and Dietrich, W.E., 1998, River longitudinal profiles and bedrock incision models: Stream Power and the influence of sediment supply. Rivers Over Rock: fluvial processes in bedrock channels, pg. 237-260

Tierney, J., 1985 Caves of Northeastern Kentucky (with special emphasis on Carter Caves State Park). In: Dougherty, P.H., (Ed.) Caves and Karst of Kentucky, Kentucky Geological Survey Special Publication 12, Series XI, Kentucky Geological Survey, Lexington, KY, p. 78-85.

Whipple, K.X., and Tucker, G.E., 1999, Dynamics of the stream-power river incision model: Implications for height limits of mountain ranges, landscape response timescales, and research needs: Journal of Geophysical Research, vol. 104, no. B8, pg. 17661-17674, DOI: 10.1029/1999JB900120.

White, E.L., and White, W.B., 1983, Karst landforms and drainage basin evolution in the Obey River Basin, North-Central Tennessee, U.S.A: Journal of Hydrology, vol. 61, p. 69-82

Wohl, E.E.,1998, Bedrock channel morphology in relation to erosional processes: In Rivers over rock: Fluvial processes in bedrock channels, pg. 133-151, Ed. K. Tinkler and W. Wohl, American Geophysics Union Momgra. 107.

Wohl, E.E., and Ikeda, H., 1998, Patterns of bedrock channel erosion on the Boso Peninsula, Japan: The Journal of Geology, vol. 106, pg. 331-345

Woodside, J., Peterson, E.W., and Dogwiler, T., 2015, longitudinal profile and sediment mobility as geomorphic tools to interpret the history of a fluviokarst stream system: International Journal of Speleology, vol. 44, issue 2, p. 197-206, doi: 10.5038/1827-086X.44.2.9 